\title{
Impacts of droughts and extreme-temperature events on gross primary production and ecosystem respiration: a systematic assessment across ecosystems and climate zones
}

Jannis von Buttlar ${ }^{1,2}$, Jakob Zscheischler ${ }^{1,3}$, Anja Rammig ${ }^{4}$, Sebastian Sippel ${ }^{1,5}$, Markus Reichstein ${ }^{1,6}$, Alexander Knohl ${ }^{2}$, Martin Jung ${ }^{1}$, Olaf Menzer ${ }^{7}$, M. Altaf Arain ${ }^{8}$, Nina Buchmann ${ }^{3}$, Alessandro Cescatti ${ }^{9}$, Damiano Gianelle ${ }^{10}$, Gerard Kiely ${ }^{11}$, Beverly E. Law ${ }^{12}$, Vincenzo Magliulo ${ }^{13}$, Hank Margolis ${ }^{14}$, Harry McCaughey ${ }^{15}$, Lutz Merbold $^{3,16}$, Mirco Migliavacca ${ }^{1}$, Leonardo Montagnani ${ }^{17}$, Walter Oechel ${ }^{18,19}$, Marian Pavelka ${ }^{20}$, Matthias Peichl ${ }^{21}$, Serge Rambal ${ }^{22}$, Antonio Raschi ${ }^{23}$, Russell L. Scott ${ }^{24}$, Francesco P. Vaccari ${ }^{23}$, Eva van Gorsel ${ }^{25}$, Andrej Varlagin $^{26}$, Georg Wohlfahrt ${ }^{27}$, and Miguel D. Mahecha ${ }^{1,6}$

${ }^{1}$ Max Planck Institute for Biogeochemistry, Hans-Knöll-Straße 10, 07745 Jena, Germany

${ }^{2}$ Georg-August-Universität Göttingen, Wilhelmsplatz 1, 37073 Göttingen, Germany

${ }^{3}$ ETH Zürich, Rämistraße 101, 8092 Zürich, Switzerland

${ }^{4}$ TUM School of Life Sciences Weihenstephan, Technische Universität München, 85354 Freising, Germany

${ }^{5}$ Norwegian Institute of Bioeconomy Research, Høgskoleveien 8, 1431 Ås, Norway

${ }^{6}$ German Centre for Integrative Biodiversity Research (iDiv) Halle-Jena-Leipzig, Deutscher Platz 5e, 04103 Leipzig, Germany

${ }^{7}$ University of California Santa Barbara, Santa Barbara, CA 93106-3060, USA

${ }^{8}$ McMaster University, 1280 Main St W, Hamilton, ON L8S 4L8, Canada

${ }^{9}$ JRC, Institute for Environment and Sustainability, TP290 Via E. Fermi, 2749, 21027 Ispra, Italy

${ }^{10}$ Fondazione Edmund Mach di San Michele all'Adige, Via E. Mach, 1, 38010 S. Michele all'Adige, Italy

${ }^{11}$ University College Cork, College Road, Cork, T12 YN60, Ireland

${ }^{12}$ Oregon State University, Corvallis, OR 97331, USA

${ }^{13} \mathrm{CNR}$, Institute for Mediterranean Forest and Agricultural Systems, via Patacca 85, 80040 Ercolano (Napoli), Italy

${ }^{14}$ Université Laval, 2325, rue de l'Université, Québec, G1V 0A6, Canada

${ }^{15}$ Queen's University, 99 University Avenue, Kingston, Ontario, K7L 3N6, Canada

${ }^{16}$ Mazingira Centre, International Livestock Research Institute (ILRI), P.O. Box 30709, 00100 Nairobi, Kenya

${ }^{17}$ Free University of Bozen-Bolzan, Piazza Università 1, 39100 Bolzano (BZ), Italy

${ }^{18}$ Global Change Research Group, San Diego State University, San Diego, CA 92182, USA

${ }^{19}$ Department of Geography, College of Life and Environmental Sciences, University of Exeter, Exeter EX4 4RJ, UK

${ }^{20}$ Global Change Research Institute CAS, Bělidla 986/4a, 60300 Brno, Czech Republic

${ }^{21}$ Department of Forest Ecology \& Management, Swedish University of Agricultural Sciences, Skogsmarksgränd,

90183 Umeå, Sweden

${ }^{22}$ Centre d'Ecologie Fonctionnelle et Evolutive CEFE, 1919, route de Mende, 34293 Montpellier 5, France

${ }^{23}$ Istituto di Biometeorologia - Sede di Firenze, Via Giovanni Caproni 8, 50145 Firenze, Italy

${ }^{24}$ Southwest Watershed Research Center, 2000 E. Allen Road, Tucson, AZ 85719, USA

${ }^{25}$ Australian National University, Acton ACT 2601, Canberra, Australia

${ }^{26}$ A.N. Severtsov Institute of Ecology and Evolution, Russian Academy of Sciences, Leninsky pr., 33, Moscow, 119071, Russia

${ }^{27}$ University of Innsbruck, Sternwartestrasse 15, 6020 Innsbruck, Austria

Correspondence: Miguel D. Mahecha (mmahecha@bgc-jena.mpg.de) 
Received: 18 September 2017 - Discussion started: 22 September 2017

Revised: 14 January 2018 - Accepted: 29 January 2018 - Published: 5 March 2018

Abstract. Extreme climatic events, such as droughts and heat stress, induce anomalies in ecosystem-atmosphere $\mathrm{CO}_{2}$ fluxes, such as gross primary production (GPP) and ecosystem respiration $\left(\mathrm{R}_{\mathrm{eco}}\right)$, and, hence, can change the net ecosystem carbon balance. However, despite our increasing understanding of the underlying mechanisms, the magnitudes of the impacts of different types of extremes on GPP and $R_{\text {eco }}$ within and between ecosystems remain poorly predicted.

Here we aim to identify the major factors controlling the amplitude of extreme-event impacts on GPP, $R_{\text {eco }}$, and the resulting net ecosystem production (NEP). We focus on the impacts of heat and drought and their combination. We identified hydrometeorological extreme events in consistently downscaled water availability and temperature measurements over a 30-year time period. We then used FLUXNET eddy covariance flux measurements to estimate the $\mathrm{CO}_{2}$ flux anomalies during these extreme events across dominant vegetation types and climate zones.

Overall, our results indicate that short-term heat extremes increased respiration more strongly than they downregulated GPP, resulting in a moderate reduction in the ecosystem's carbon sink potential. In the absence of heat stress, droughts tended to have smaller and similarly dampening effects on both GPP and $\mathrm{R}_{\text {eco }}$ and, hence, often resulted in neutral NEP responses. The combination of drought and heat typically led to a strong decrease in GPP, whereas heat and drought impacts on respiration partially offset each other. Taken together, compound heat and drought events led to the strongest $\mathrm{C}$ sink reduction compared to any single-factor extreme. A key insight of this paper, however, is that duration matters most: for heat stress during droughts, the magnitude of impacts systematically increased with duration, whereas under heat stress without drought, the response of $R_{\text {eco }}$ over time turned from an initial increase to a downregulation after about 2 weeks. This confirms earlier theories that not only the magnitude but also the duration of an extreme event determines its impact.

Our study corroborates the results of several local sitelevel case studies but as a novelty generalizes these findings on the global scale. Specifically, we find that the different response functions of the two antipodal land-atmosphere fluxes GPP and $\mathrm{R}_{\text {eco }}$ can also result in increasing NEP during certain extreme conditions. Apparently counterintuitive findings of this kind bear great potential for scrutinizing the mechanisms implemented in state-of-the-art terrestrial biosphere models and provide a benchmark for future model development and testing.

\section{Introduction}

\subsection{Overview}

Extreme climatic events such as heat or drought are key features of Earth's climatic variability (Ghil et al., 2011) and occur on a wide range of timescales (Huybers and Curry, 2006). Extreme climatic events directly propagate into the terrestrial biosphere, thus affecting ecosystem functioning (Reichstein et al., 2013; Frank et al., 2015) and land surface properties (e.g., soil moisture), which in turn triggers ecosystematmosphere feedback loops (e.g., Seneviratne et al., 2010; Green et al., 2017). For example, drought in conjunction with severe heat reversed several years of ecosystem carbon sequestration in Europe in 2003 (Ciais et al., 2005), and strong land-atmosphere feedbacks exacerbated the event while it was occurring (Fischer et al., 2007).

However, ecosystem impacts of extreme climatic events are often nonlinear and interact with concurrent climatic conditions. Additionally, potential impacts can cancel each other out depending on the type and state of the ecosystem and the magnitude of the climatic event. For instance, extremely warm conditions at the beginning of the growing season during spring 2012 in the contiguous US increased ecosystem carbon uptake, which subsequently compensated for ecosystem carbon losses later during the same year's summer heat and drought. Nonetheless, warm spring conditions and corresponding earlier vegetation activity likely also contributed to exacerbating drought impacts through reduced initial soil moisture at the onset of summer drought (Wolf et al., 2016).

Because extreme climate events have been changing in recent decades, with, for example, a general increase in the amount of warm days and the duration of warm spells and the opposite trend for cold days and spells (Sillmann et al., 2013a), and are projected to continue to change (Sillmann et al., 2013b), an understanding of their impacts on ecosystems is crucial. Ideally, this understanding would cover ecological processes that operate on both local and global scales. However, due to nonlinear and interacting ecosystem effects of climate extremes, differences in ecosystem responses across various growing season stages (Wolf et al., 2016) and various ways in which different ecosystem types mediate climatic extremes (e.g., Teuling and Seneviratne, 2011), it currently remains unclear whether a global perspective on ecosystem responses to climate extremes can emerge from local-scale observations alone. Moreover, understanding ecosystem responses to climate extremes is crucial in the context of potentially increasing intensities or frequencies of climatic extremes that could lead to a positive carbon-cycleclimate feedback via a reduction in the land carbon sink. 


\subsection{Stress ecophysiology of photosynthesis and respiration}

Gross primary production (GPP), which is carboxylation rate (i.e., true photosynthesis) minus photorespiration (Wohlfahrt and $\mathrm{Gu}, 2015)$, is strongly impacted by temperature and water stress (Reichstein et al., 2013). Besides its other main environmental drivers (radiation, humidity (i.e., vapor pressure deficit, VPD) and $\mathrm{CO}_{2}$ concentration, cf. Leuning, 1990), temperature directly influences photosynthesis by affecting the kinetics of its two main chemical processes, namely the maximum rates of carboxylation (i.e., $V_{\mathrm{c}, \max }$; Farquhar et al. (1980)) and electron transport (i.e., $J_{\max }$; e.g., Medlyn et al., 2002; Sage and Kubien, 2007). Both rates initially increase with rising temperature but decrease above a certain optimum temperature (Bonan, 2008). Leaf (i.e., light) respiration similarly increases with temperature (Leuning, 1990), which additionally reduces GPP. As a result, extremely high temperatures can severely reduce photosynthesis (and, hence, GPP) (Salvucci and Crafts-Brandner, 2004; Allakhverdiev et al., 2008).

Soil water stress impacts photosynthesis (see, e.g., van der Molen et al., 2011, for a review) by causing either ecophysiological or structural changes to the plant (Schulze, 1986; Chaves, 1991). For instance, a physiological reduction in photosynthesis can be caused by reductions in enzymatic activity (Chaves et al., 2009; Keenan et al., 2010; van der Molen et al., 2011) or a reduction in mesophyll and stomatal conductance (e.g., Flexas and Medrano, 2002; Bréda et al., 2006). Structural changes reducing photosynthesis include reductions in leaf area and specific leaf area or changes in leaf geometry or orientation (Bréda et al., 2006; Fisher et al., 2007). Via increased tree mortality, droughts can also severely impact ecosystem-level photosynthesis long after the drought event itself (e.g., Bréda et al., 2006; Bigler et al., 2007).

All these responses are highly species dependent, highlighting the need for global cross-site analyses. For example, forest species generally close their stomata much earlier compared to species from grassland or savannah ecosystems, which often keep transpiring until their water storage is depleted (Wolf et al., 2016). In addition, anisohydric plants in general have no control over their stomata (van der Molen et al., 2011). A soil-dependent factor increasing the ecosystem's drought resilience is the rooting depth and the general availability of fine roots (Bréda et al., 2006).

In addition, interactions between heat and drought may affect GPP. For example, drought-induced closing of the stomata and the subsequent reduction in evaporative cooling can further increase heat stress when water stress co-occurs with a high-temperature anomaly (De Boeck and Verbeeck, 2011; Bréda et al., 2006). Conversely, high-temperature impacts can be alleviated by evaporative cooling as long as enough water for transpiration is available (De Boeck et al., 2010).
Ecosystem respiration $\left(\mathrm{R}_{\mathrm{eco}}\right)$ is the sum of autotrophic respiration and the $\mathrm{CO}_{2}$ emissions arising from the heterotrophic decomposition of organic matter in soil (e.g., Law et al., 1999, 2001; Epron et al., 2004). Like GPP, it is affected by changing soil (and, hence, ambient air) temperatures (Lloyd and Taylor, 1994; Kirschbaum, 1995; Davidson et al., 1998; Kirschbaum, 2006). Rising temperatures directly increase the kinetics of microbial decomposition, root respiration and the diffusion of enzymes. Hence, soil respiration is commonly modeled as an exponential function of temperature using the van't Hoff type $Q_{10}$ model (van't Hoff, 1898; Jassal et al., 2008; Mahecha et al., 2010) or other functions of a similar shape (e.g., Kätterer et al., 1998; Kirschbaum, 1995; Reichstein and Beer, 2008). Even though enzyme activity generally decreases above a certain temperature optimum (Kirschbaum, 1995), such high temperatures rarely occur in extratropical soils (Reichstein and Beer, 2008), so high temperatures alone are rarely an inhibiting stressor for soil respiration.

In addition, the activity of soil microorganisms depends on soil moisture (Orchard and Cook, 1983; Gaumont-Guay et al., 2006; Liu et al., 2009; Epron et al., 2004). Drought conditions strongly reduce soil respiration because the microbial activity causing soil respiration is dependent on the presence of water films for substrate diffusion and exoenzyme activity (Davidson and Janssens, 2006; Jassal et al., 2008; Frank et al., 2015). In addition, low soil water status may even cause microbial dormancy and/or death (Orchard and Cook, 1983). Indirectly, drought reduces microbial activity through different processes like the alteration of soil nutrient retention and availability (Muhr et al., 2010; Bloor and Bardgett, 2012) or changes in microbial community structure (Sheik et al., 2011; Frank et al., 2015). Finally, interactions between the response to temperature and water status, such as changing temperature dependency due to changing soil water status (Reichstein et al., 2002; Reichstein and Beer, 2008), further complicate the picture.

As described above, both heat and drought affect GPP and $\mathrm{R}_{\text {eco }}$ in a similar fashion, although the amplitude and onset of this impact may differ. Hence, one important, partly unanswered question is the impact of climate extremes on the balance of these two fluxes: the net ecosystem production (NEP). Models tend to agree that drought affects GPP more strongly than $\mathrm{R}_{\mathrm{eco}}$, but their spread is large and predictions for the $\mathrm{C}$ balance are uncertain (Zscheischler et al., 2014b). In addition, observational studies on large drought and heat events like the 2003 European heat wave (Ciais et al., 2005; Vetter et al., 2008; Reichstein et al., 2007; Granier et al., 2007) or the 2000-2004 drought in North America (Schwalm et al., 2012) have shown, for example, that drought may cause a much stronger reduction in GPP compared to $\mathrm{R}_{\mathrm{eco}}$, leading to a reduction in the ecosystem's $\mathrm{CO}_{2}$ uptake.

However, it is important to understand that the tight coupling between GPP and $\mathrm{R}_{\mathrm{eco}}$ in most ecosystems (Irvine et al., 2008; Mahecha et al., 2010; Migliavacca et al., 2010; 


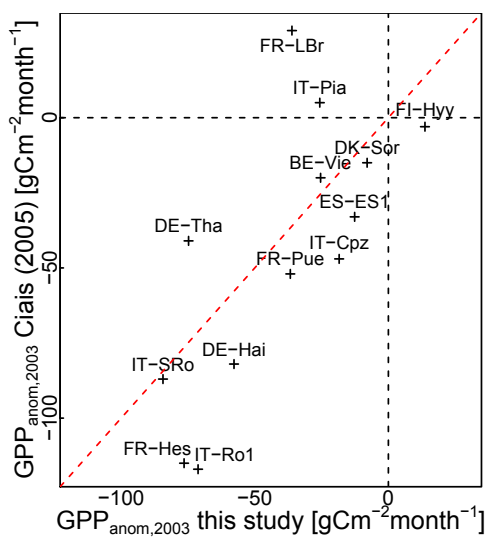

Figure 1. Comparison of the gross primary productivity (GPP) reductions during the 2003 European heat wave for several FLUXNET sites. Ciais et al. (2005) quantified this reduction by comparing the 2003 fluxes to the previous year, whereas we are able to use all available site years as a baseline.

van der Molen et al., 2011; Peichl et al., 2013; Rambal et al., 2014) complicates systematic assessments across sites. For example, heterotrophic respiration is not only a function of the environment but is also strongly driven by the availability of recently assimilated carbon (Irvine et al., 2005; Granier et al., 2007; Ruehr et al., 2012). Hence, a reduction in photosynthesis may cause a lagged reduction in soil respiration (Law, 2005; Ryan and Law, 2005; Jassal et al., 2012) in the absence of a large labile carbon stock.

\subsection{Today's opportunities}

The majority of studies so far focus on individual sites and predefined extreme events (see Frank et al., 2015, for a review) and only a few have focused on comparisons of extreme-event impacts globally across sites and/or across broader regions and different ecosystems (Schwalm et al., 2010, 2012). The La Thuile dataset collected by FLUXNET consists of 252 sites of eddy covariance flux observations in a standardized way (Baldocchi, 2008). These data provide a basis for a robust assessment of the impacts of climatic extremes on ecosystem $\mathrm{CO}_{2}$ fluxes. The opportunities arising from this trove of observations are exemplified in Fig. 1. The figure recalculates the impacts of the 2003 heat wave on land fluxes as estimated by Ciais et al. (2005) using more reference years based on the data available. The general findings of Ciais et al. (2005), who showed a strong reduction in C uptake, are confirmed, but we now estimate a lower reduction in $\mathrm{CO}_{2}$ uptake when considering more reference years, which is consistent with Vetter et al. (2008), who found a similar pattern using models. Consequently, the length of today's data records and in particular the tremendous work of the numerous networks and initiatives (see Acknowledgements) who collect these data and provide them to the scientific commu-

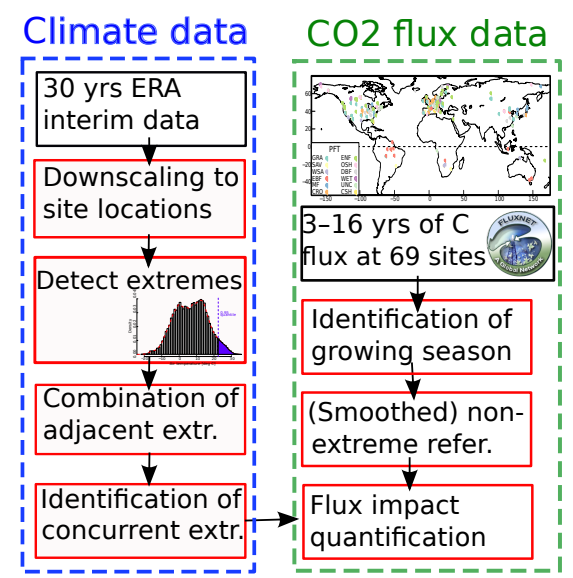

Figure 2. Conceptual overview of the different data streams and successive steps of our analysis.

nity allow us to update previous quantifications of the $\mathrm{CO}_{2}$ flux impacts of climate extremes.

\subsection{Objectives of this study}

The objectives of this study are threefold: first, we want to exploit the available FLUXNET data to systematically assess if extreme events corroborate our assumptions about ecosystem behavior and to empirically describe the spectrum of extreme responses across the globe. To do so, we extract information about the occurrence of an extreme climatic event directly from the observed data, not by first assuming the occurrence of an extreme event (i.e., by identifying an extreme response of the observed ecosystem). Second, our goal is to develop an extreme-event detection framework with a focus not only on the extremeness of the climate forcing but which simultaneously takes into account the resulting extremeness of the ecosystem's response or lack thereof (Smith, 2011; Reichstein et al., 2013). Finally, we aim to bridge the gap between local site-level studies and global assessments, which most often are based on models (e.g., Cramer et al., 1999; Friedlingstein et al., 2006) or upscaling studies (Beer et al., 2010; Jung et al., 2017) by providing some helpful benchmarks for the models and their underlying assumptions (Canadell et al., 2000; Williams et al., 2009).

\section{Methods}

\subsection{Study concept and overview}

Our study can be outlined as a three-step process (Fig. 2): first, we use consistently downscaled climate data (Sect. 2.3) to detect climatic extreme events (Sect. 2.4) during the growing season in a set of ecosystems. Second, we compare $\mathrm{CO}_{2}$ fluxes (Sect. 2.2) during these extreme events with reference fluxes during comparable, non-extreme periods to quantify 
the impact of each extreme event (Sect. 2.5). Third, we use site-specific information like plant functional type (PFT) or ecoclimatic zone (Geiger-Köppen climate classes) as well as climate extreme characteristics (including type and duration) to systematically assess potential causes of differences between extreme-event responses in the different ecosystems.

\section{$2.2 \mathrm{CO}_{2}$ flux data}

Measurements of $\mathrm{CO}_{2}$ flux and climate parameters collected through a network of measurement sites were used in this study. $\mathrm{CO}_{2}$ fluxes were measured using the eddy covariance technique (e.g., Moncrieff et al., 1997; Baldocchi, 2003). The measured net carbon flux (i.e., net ecosystem exchange, NEE) was partitioned into GPP and $\mathrm{R}_{\text {eco }}$ (Reichstein et al., 2005) at each site. The empirical relationships used by this partitioning scheme assume similar ecophysiological conditions for any given time step (e.g., for one of the extreme events detected here) and a short reference period is used to fit these empirical functions. Environmental stress, however, could also directly impact the processes governing these empirical relationships and hence the validity of this assumption. To assess whether this could bias our analysis, we also performed all of our calculations using midday NEE as a rough estimate for GPP and averaged nighttime NEE as a proxy for $\mathrm{R}_{\text {eco }}$ (Reichstein et al., 2005).

Throughout the rest of the paper, we refer to NEP instead of NEE (i.e., $\mathrm{NEP}=\mathrm{GPP}-\mathrm{R}_{\text {eco }}=(-1) \cdot \mathrm{NEE}$ ) because NEP is centered on the ecosystem (i.e., positive NEP equals $\mathrm{CO}_{2}$ uptake) and facilitates a more intuitive interpretation together with the component fluxes GPP and $\mathrm{R}_{\mathrm{eco}}$.

Eddy covariance measurements are continuously taken at various sites across the globe by individual research teams and are collected and consistently processed by the FLUXNET network (Baldocchi et al., 2001; Baldocchi, 2008, 2014). For this analysis, we used the FLUXNET La Thuile dataset, which consists of a total of 252 sites. We used additional data from the European eddy fluxes database cluster (http://www.europe-fluxdata.eu/) for site years collected since the creation of the La Thuile dataset in 2007. Both networks consistently filter the submitted data for potential outliers. The half-hourly measurements supplied by the data providers are consistently gap-filled via marginal distribution sampling (MDS) (Reichstein et al., 2005), i.e., by filling missing values with measurements taken under similar meteorological conditions, and aggregated to daily mean values. For this analysis we used only daily aggregates and excluded data for days with less than $85 \%$ original measurements or high confidence gap-filled data.

To be able to compare flux measurements during a potential extreme event with fluxes during non-extreme conditions during comparable stages of the phenological cycle in other years, we selected 102 sites with time series longer than 3 years. In addition, we removed four sites where the correlation between downscaled climate data and measured site meteorology was too low $\left(R^{2}<0.6\right)($ Sect. 2.3) and four sites where water availability (Sect. 2.3 ) could not be calculated due to missing data. Finally, we excluded 25 managed and disturbed sites where disturbances such as fire and thinning would have resulted in biases in the calculations of the non-extreme reference data in years before or after the disturbance. This resulted in a subset of 69 sites (Table A3) out of the original $252 \mathrm{La}$ Thuile sites, with a total of 433 site years of data (i.e., years with data available for more than $75 \%$ of all days). These sites span 11 PFTs including grasslands, wetlands and forest type ecosystems (Table A1) and all major Geiger-Köppen climate zones (Table A2) (i.e., first category zones A-E), as well as half of the 24 Geiger-Köppen subzones (i.e., the secondary categories).

\subsection{Climate data}

To be able to identify extreme events over sufficiently long and consistent time periods for all sites, compared to the much shorter time periods where actual measurements were available, we used downscaled climate data for the extremeevent detection. We used daily air temperature and, for the calculation of the water availability (see below), global radiation and precipitation from ERA-Interim data (Dee et al., 2011) at a $0.5^{\circ}$ spatial resolution (i.e., the area of 1 pixel $\left.\leq(55 \mathrm{~km})^{2}\right)$.

Multiple linear regression models of the nearest nine grid boxes (i.e., the grid box with the tower and its direct neighbor pixels) were fitted to FLUXNET site-level meteorology measurements. The resulting models were used to predict site-level values for a time period of 30 years between 1983 and 2012. The resulting time series were then used to detect climate extremes. The correlation between downscaled and site-level data for air temperature was $R^{2}>0.9$ for nearly $90 \%$ of the sites. Sites with $R^{2}<0.6(\approx 5 \%$ of the sites, mainly tropical evergreen broad-leaved forests) were removed from the analysis due to the low quality of the downscaling.

To consistently quantify the amount of soil water available to the plant, a water availability index (WAI) was calculated. This index was based on the water balance between precipitation and evapotranspiration and was calculated as a simple two-layer bucket model (see Supplement 3 in Tramontana et al., 2016, for detailed equations, etc.). At each time step, the soil is recharged with water by precipitation up to a maximum value defined by the storage capacity $(125 \mathrm{~mm})$. Losses of water by evapotranspiration are taken as the minimum of either potential evapotranspiration or supply-limited evapotranspiration. Potential evapotranspiration is estimated based on Priestley and Taylor (1972) from net radiation (also taken from the reanalysis data) using a Priestley-Taylor coefficient of 1.26. Potential evapotranspiration is then finally scaled with smoothed fAPAR (fraction of absorbed photosynthetically active radiation) (from MODIS, Moderate-resolution Imaging Spectroradiometer). Supply-limited evapotranspira- 
tion is calculated following Teuling et al. (2009) and is simply defined as a fraction (i.e., 0.05 , the median of the values determined by Teuling et al., 2009) of current WAI. Assuming that both water recharge (i.e., precipitation) and water loss (i.e., evapotranspiration) operate from top to bottom, WAI was computed for a simple two-layer model, where the storage capacity of the upper layer was set to $25 \mathrm{~mm}$ and that of the lower layer to $100 \mathrm{~mm}$. Only WAI of the lower layer was used in the subsequent analysis and scaled to $0-1$ (by dividing by the maximum capacity of 100).

The WAI does not account for local soil or vegetation specific properties such as soil texture or rooting depth. such that the WAI may be interpreted as a "climatological water availability metric". The results are sensitive to the fixed value of storage capacity, which influences the timing and magnitude of extreme drought events. For example, a larger (smaller) storage capacity value would tend to result in a later (earlier) extreme-drought detection. We are confident, however, that these changes would not strongly bias the qualitative and global patterns of the flux impacts investigated in this analysis.

\subsection{Extreme-event detection}

Extreme events were defined and detected in the following stepwise procedure:

1. identification of single extreme data points (i.e., days) crossing the upper and lower 5 th percentile threshold

2. combination of temporally connected single extreme data points into extreme events

3. identification of co-occurring extreme events of different variables to classify concurrent extremes.

A percentile-based approach (Seneviratne et al., 2012; Zscheischler et al., 2014a) was used to define the upper and lower 5th percentile of the original distribution as extreme (subscript max and min; cf. Table 1). Due to the strong seasonal cycles of air temperature and WAI at most outer tropical sites, this definition resulted in extreme events mainly being detected in summer and winter and represents a means for capturing extreme conditions beyond an actual value with direct physiological meaning.

However, from an ecosystem physiological perspective, an extreme climatic event can also occur outside the maximum or minimum period of the year (e.g., during spring or fall for temperature). To detect such extreme events, air temperature time series were deseasonalized by subtracting a mean annual cycle (MAC) to yield anomalies. The MAC was computed as the daily average of all 30 years and smoothed with a 2-week moving average. The upper (and lower) 5th percentiles of these anomalies were defined as extreme (subscript anom, max and anom, min) (Table 1 for all extremeevent notations used). Such anomaly extremes were only de-
Table 1. Overview of different extreme-event types and the suffixes denoting them.

\begin{tabular}{ll}
\hline Label & Extreme type \\
\hline $\mathrm{T}_{\max } / \mathrm{T}_{\min }$ & temperature maximum/minimum \\
$\mathrm{WAI}_{\min }$ & water availability minimum (i.e., drought) \\
$\mathrm{T}_{\text {anom, max }}$ & temperature anomaly maximum \\
$\mathrm{T}_{\max }, \mathrm{s} / \mathrm{WAI}_{\min , \mathrm{s}}$ & $\begin{array}{l}\text { temperature/WAI extreme without the other } \\
\text { variable being extreme } \\
\mathrm{T}_{\max }+\mathrm{WAI}_{\min }\end{array}$ \\
& $\begin{array}{l}\text { concurrent extreme with both temperature } \\
\text { and WAI being extreme }\end{array}$ \\
\hline
\end{tabular}

tected for air temperature because seasonally varying sensitivity to water availability is not expected.

After the identification of single extreme time steps (i.e., days), contiguous extreme time steps were concatenated into extreme events. Additionally, two successive but not contiguous extreme events were subsequently treated as one single long extreme event if the non-extreme period between them was shorter than $20 \%$ of the combined length of the two extreme events together. This prevented short-term fluctuations in temperature (WAI did not usually fluctuate so quickly) below the extreme threshold during one long period of high temperature from separating this period into smaller extreme events and allowed for a more realistic assessment of the extreme-event duration (see below).

To differentiate between the effects of univariate extremes and the possibility of different impacts of simultaneous extremes of heat and drought, the following types of extreme events were differentiated: (1) single variable extreme events irrespective of the possible extremeness of other variables (denoted T/WAI $\mathrm{Iin}_{\mathrm{min}}$ ), (2) single variable extreme events without other variables being extreme (denoted, for example, as $\mathrm{T}_{\max , \mathrm{s}}$ or $\mathrm{WAI}_{\min , \mathrm{s}}$ ) and (3) concurrent extremes (Seneviratne et al., 2012; Leonard et al., 2014), i.e., coupled extreme events with multiple variables being extreme $\left(\mathrm{T}_{\max }+\mathrm{WAI}_{\min }\right)$ (Table 1 for an overview).

Finally, all extreme events were described by characteristics such as duration and type (see above) to identify which of these factors influence the type and magnitude of possible impacts. At this first stage we did not consider several other ecosystem specific important factors which influence the ecosystem's response to climatic extremes such as site history and detailed species composition (e.g., Law, 2014). Such an analysis should be generally possible at future stages (Sect. 3.6); however, the relevant information first has to be gathered across all sites in a standardized and comparable way.

\subsection{Flux impact calculations}

To identify those events that actually have a physiological impact among all the detected climatic extreme events, a con- 
sistent quantification of the actual impact on the ecosystem was required.

To do so, differences between the mean of the fluxes during the extreme event and comparable reference periods were computed (see, e.g., Ciais et al., 2005; Schwalm et al., 2012; van Gorsel et al., 2016; Wolf et al., 2016, for a similar approach). These reference periods were defined to be nonextreme, identical days of the year (DOY) from all other available years. For the reference period, the mean was computed from a moving-average smoothed time series (i.e., 14day moving-average filtering computing the median) to minimize the influence of stochastic fluctuations. During the actual extreme event, however, non-smoothed data were used to compute these means.

$\Delta f=\bar{f}_{\text {extr }}-\bar{f}_{\text {ref }}=\frac{1}{n} \sum_{k=i}^{i+n-1} f_{k}-\frac{1}{n y} \sum_{k=j} f_{k}$

Here, $f$ denotes the respective $\mathrm{CO}_{2}$ flux (NEP, GPP or $\mathrm{R}_{\text {eco }}$ ), $i$ denotes the first day of one particular extreme event of length $n, j$ denotes the identical (and not extreme) days of the year (DOY) in all other years, and $y$ is the number of reference years.

As the amplitudes of $\mathrm{R}_{\mathrm{eco}}$ and GPP differ significantly between highly productive and less productive ecosystems, all analyses were done for original (Eq. 1) and for $z$-transformed time series:

$\Delta z=\bar{z}_{\mathrm{extr}}-\bar{z}_{\mathrm{ref}}=\frac{1}{n} \sum_{k=i}^{i+n-1} z_{k}-\frac{1}{n y} \sum_{k=j} z_{k}$,

with

$z_{k}=\frac{f_{k}-\bar{f}}{\hat{\sigma}(f)}$

for all $k$.

Even though extreme events outside the growing season, such as extreme-frost periods in winter, can have impacts on the ecosystem's carbon fluxes, such impacts would be lagged in many cases (i.e., visible during the following growing season). Because only instantaneous responses were investigated with our framework, it was necessary to exclude such extreme events from the analysis. To identify the growing season, a spline function was used to smooth the time series of GPP. In the first step, all smoothed values above the 25th percentile were considered to be the growing season. Subsequently, in each year these periods were extended at the beginning and end of the detected period by identifying the first day when the smoothed series dropped below the 5th percentile.

\section{Results and discussion}

We begin by discussing the different effects of heat and drought on primary production and respiration observed on a

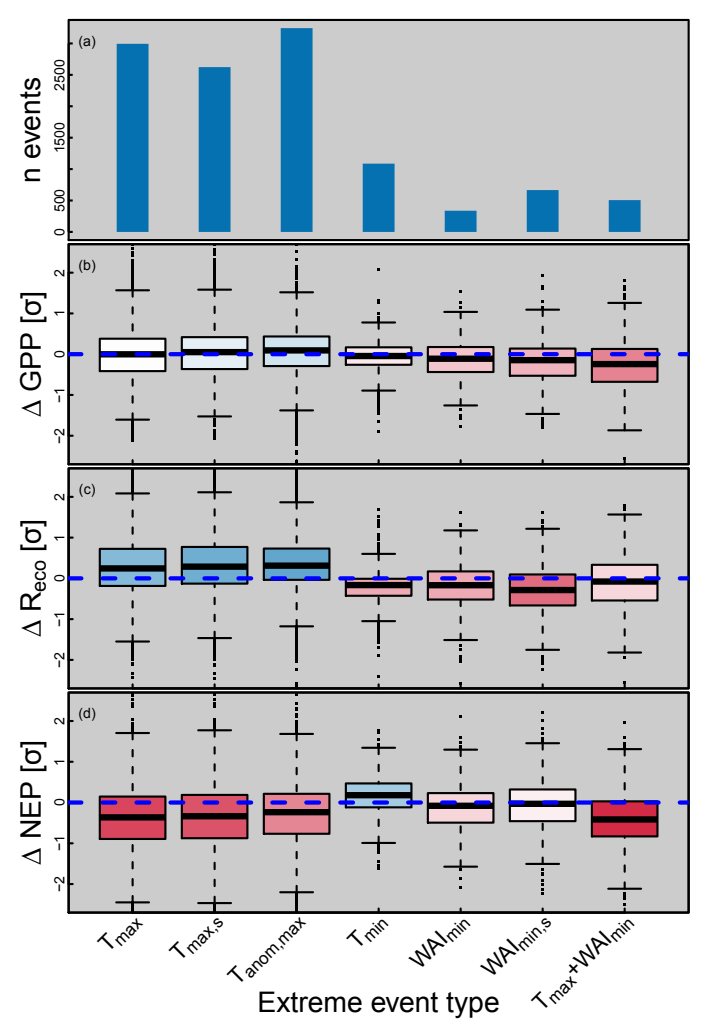

Figure 3. Impacts of different extreme-event types for a selection of different extreme-event types (heat $\left(\mathrm{T}_{\max }\right)$, heat only $\left(\mathrm{T}_{\max } \mathrm{s}\right)$, temperature anomalies extreme $\left(\mathrm{T}_{\mathrm{anom}} \mathrm{s}\right)$, cold $\left(\mathrm{T}_{\mathrm{min}}\right)$, drought $\left(\mathrm{WAI}_{\min }\right)$, drought only $\left(\mathrm{WAI}_{\min , \mathrm{s}}\right)$ and combined drought and heat $\left(\mathrm{T}_{\max }+\mathrm{WAI}_{\min }\right)$; see Table 1 for details on all extreme types) on gross primary production (GPP), ecosystem respiration $\left(\mathrm{R}_{\mathrm{eco}}\right)$ and net ecosystem production (NEP). Shown are differences between the normalized fluxes (i.e., their $z$ scores) during a nonextreme reference period and the fluxes during the extreme event ( $\Delta z=z_{\text {extr }}-z_{\text {ref }}$; see Eqs. 2 and 3 for details). Box plots are colorcoded according to the median of the distribution with shades of blue (for positive values, i.e., a flux increase during the extreme event) and red (for negative/decreased values). Panel (a) shows the amount of growing season extreme events detected for each event type. Panel (b) shows the impacts on GPP, (c) on $R_{e c o}$ and (d) on NEP.

global scale (i.e., averaged over all ecosystems). The different responses to concurrent heat and drought extreme events in contrast to heat- or drought-only events are highlighted and discussed in Sect. 3.2. The crucial role that the duration of the extreme event plays with regard to its impact is discussed in Sect. 3.3, and the response of different ecosystem types or PFTs that may explain the large spread of the impacts is considered in Sect. 3.4. We conclude by discussing strengths and limitations of the approach presented here (Sect. 3.5) and examining future directions (Sect. 3.6). 


\subsection{Contrasting impacts of heat vs. drought on GPP and $R_{\text {eco }}$}

High-temperature extremes without particularly low water availability (i.e., $\mathrm{T}_{\max }, \mathrm{T}_{\text {anom, } \max }, \mathrm{T}_{\max , \mathrm{s}}$ and $\mathrm{T}_{\text {anom, max, } \mathrm{s}}$ ) had only small or virtually zero impacts on GPP (Fig. 3), which is consistent with earlier findings (e.g., for the European heat wave 2003; Reichstein et al., 2007). This averaged effect can be partly explained by the specific response of different ecosystem types (see Sect. 3.4). Heat extremes in general tended to have no or only a small negative impact on observed rates of GPP in most cases. Even though GPP has been shown to have clear temperature optima and decreases at high temperatures due to enzyme inhibition (Bernacchi et al., 2001; Medlyn et al., 2002; Larcher, 2003), such conditions (i.e., temperatures well above $30^{\circ} \mathrm{C}$ ) are experienced only rarely in the (mostly temperate and Mediterranean) sites investigated. Other studies also confirm the small impact of heat alone on GPP (De Boeck et al., 2010). Only for very long and pronounced extreme events was a clear negative impact on GPP observed (discussed in detail in Sect. 3.3).

In our analysis, water scarcity events (i.e., $\mathrm{WAI}_{\min }$ and $\mathrm{WAI}_{\text {min, s }}$ ) in general showed a reduction in GPP and $\mathrm{R}_{\mathrm{eco}}$, which, due to compensation of these component fluxes, led to no discernible changes in NEP on average over the considered FLUXNET sites (Fig. 3). In contrast, events in which low water availability coincided with heat led to a very strong reduction in GPP but a lesser reduction in $\mathrm{R}_{\text {eco }}$ and as a consequence to the strongest reduction in carbon uptake (see Sect. 3.2 for a more detailed discussion). Such a strong effect of droughts (compared to high temperatures alone) on GPP and the generally decreasing effect of drought on GPP is consistent with other studies (e.g., Ciais et al., 2005; Zhao and Running, 2010; Wolf et al., 2013; Zscheischler et al., 2014a, d, c) where water stress directly forces plants to close their stomata to limit transpiration, reducing photosynthesis. Similarly, Jung et al. (2017) found that water availability is a much bigger control on the interannual variability in GPP (IAV, which is controlled to a large degree by extreme events) compared to a smaller temperature control on a global level.

In contrast to the small response of GPP to heat, however, $\mathrm{R}_{\mathrm{eco}}$ generally increased during most high-temperature extreme events (Fig. 3). As a consequence, NEP decreased, which represents reduced carbon uptake of the ecosystem. Rising temperatures in general lead to an increase in the microbial degradation of biomass (Mahecha et al., 2010), which explains rising $\mathrm{R}_{\mathrm{eco}}$ rates during short periods of high temperatures as observed in other studies (Rustad et al., 2001; Wu et al., 2011; Zhao and Running, 2010; Anderson-Teixeira et al., 2011; van Gorsel et al., 2016). An additional factor could be higher radiation inputs, which result in increased photodegradation in relatively open non-forest ecosystems.

Compared to temperature, soil respiration as the main component of $\mathrm{R}_{\mathrm{eco}}$ is regulated much more strongly by soil water availability (Meir et al., 2008). Droughts in general in our study led to a similar reduction in $\mathrm{R}_{\text {eco }}$ compared to GPP. The reason for this could be the inhibition of soil microbial processes due to moisture limitation. Additionally, a decrease in GPP also results in a coupling of the two fluxes and, hence, also leads to a reduction in $\mathrm{R}_{\text {eco }}$ (Högberg et al., 2001; Meir et al., 2008). The compensating effect of drought-induced reductions in both GPP and $\mathrm{R}_{\text {eco }}$ resulted in small or negligible changes in NEP, which also has been demonstrated at local (e.g., Law, 2005; Meir et al., 2008) and global (Jung et al., 2017) levels.

\subsection{The differentiated impacts of concurrent heat and drought events on GPP and $R_{\text {eco }}$}

In contrast to the single-factor extreme events discussed above, concurrent heat and drought extremes $\left(\mathrm{T}_{\max }+\right.$ $\mathrm{WAI}_{\min }$ ) led to a much stronger reduction in GPP in most cases. By contrast, $\mathrm{R}_{\mathrm{eco}}$ was not so strongly (or not at all) reduced. This resulted in the strongest NEP (i.e., $C$ sink) reduction in any extreme event (Fig. 3).

Several studies have found a lower drought sensitivity of $\mathrm{R}_{\text {eco }}$ compared to GPP (Ciais et al., 2005; Schwalm et al., 2010, 2012; Rambal et al., 2014; Zscheischler et al., 2014d) whereas we observed comparable or even slightly greater reductions during drought-only ( $\mathrm{WAI}_{\mathrm{min}, \mathrm{s}}$ ) extremes on the global scale. The strong drought extremes investigated in these studies, however, usually coincided with heat extremes and are hence more comparable to our concurrent heat and drought extremes $\left(\mathrm{T}_{\max }+\mathrm{WAI}_{\min , \mathrm{s}}\right)$ where we also see a nearly negligible mean effect on $\mathrm{R}_{\mathrm{eco}}$ (compared to GPP).

NEP is the sum of the opposing fluxes of GPP and $R_{\text {eco }}$, and hence, the direction and amplitude of its change is always determined by the sum of the extreme-event impacts on the gross fluxes. For heat extremes, the general increase in $\mathrm{R}_{\mathrm{eco}}$ adds to slight decreases (or no change) in GPP, leading to a generally reduced rate of net carbon uptake. For only drought (and no heat) extremes, the reductions in both GPP and $R_{\text {eco }}$ seem to roughly cancel each other out, leading to no strong effects on NEP (again, as a FLUXNET average). However, during the concurrent heat and drought extremes, $\mathrm{R}_{\text {eco }}$ is less strongly reduced than GPP (and also compared to only drought extremes), leading to strong reductions in net carbon uptake compared to non-extreme conditions. Part of this effect can be explained by the compensating and opposite effects of heat and drought on $\mathrm{R}_{\mathrm{eco}}$ (Ciais et al., 2005).

While our analysis confirms a crucial impact of dryness on the individual carbon fluxes GPP and $\mathrm{R}_{\mathrm{eco}}$, it also shows that drought extreme events in which dryness coincides with $\mathrm{T}_{\max }$ extremes have a disproportionately large negative impact on the net carbon balance (i.e., compare also Fig. 4 lowest panels on the right side), which is consistent with model results (Zscheischler et al., 2014b). The combined effect of dryness and heat might be interpreted in a process-oriented way in that dryness acts primarily to reduce GPP, while heat increases $\mathrm{R}_{\mathrm{eco}}$, thus both leading to a severe reduction in net 


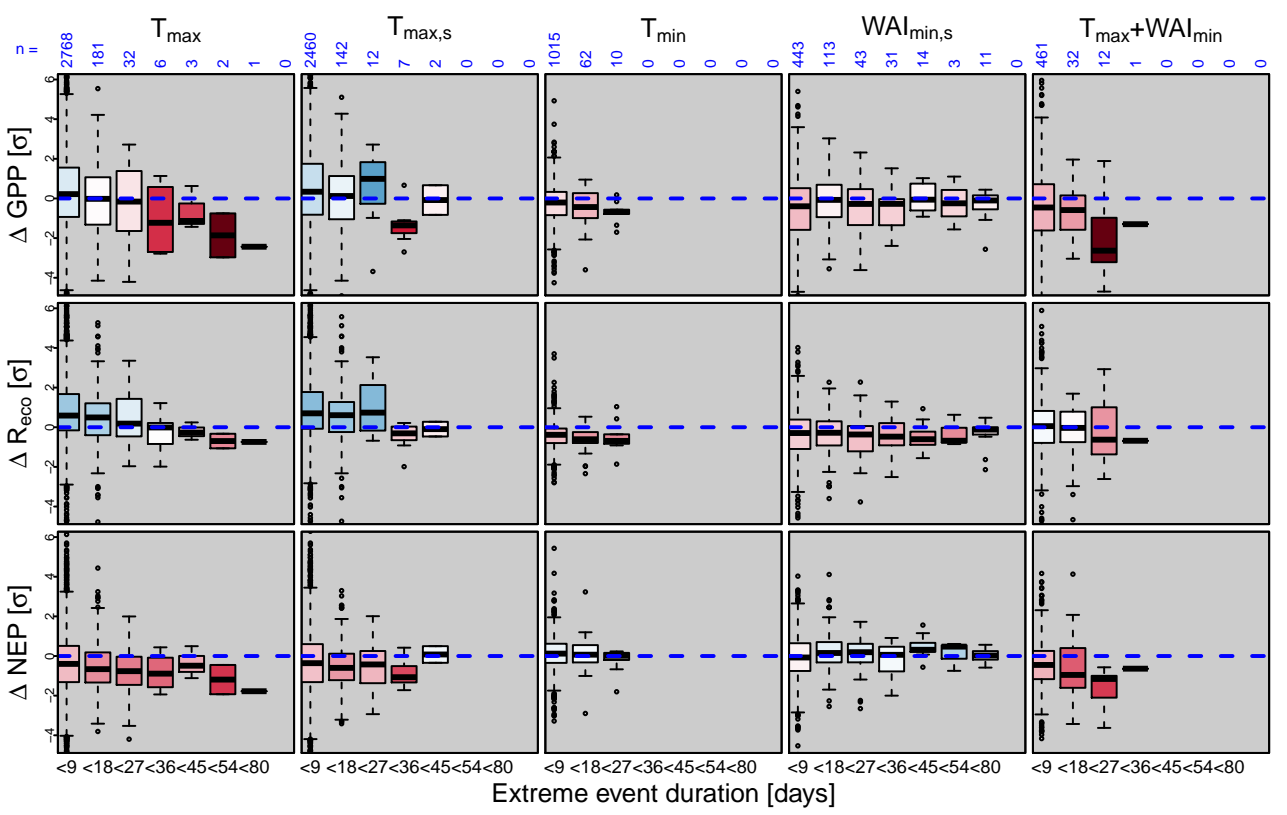

Figure 4. Influence of extreme-event duration on extreme-event impact. Shown are normalized flux differences between extreme events and a reference period $\left(\Delta z=z_{\text {extr }}-z_{\text {ref }}\right.$; see Eqs. 2 and 3 for details) for gross primary production (GPP), ecosystem respiration (R $\left.\mathrm{R}_{\mathrm{eco}}\right)$ and net ecosystem production (NEP) (in rows 1-3) for a selection of different extreme-event types (in columns $1-5$ : heat $\left(\mathrm{T}_{\max }\right)$, heat only $\left(\mathrm{T}_{\max } \mathrm{s}\right)$, cold $\left(\mathrm{T}_{\min }\right)$, drought only $\left(\mathrm{WAI}_{\min , \mathrm{s}}\right)$, and combined drought and heat $\left(\mathrm{T}_{\max }+\mathrm{WAI}_{\min }\right)$; see Table 1 for details on all extreme types). Blue numbers at the top margin of the figure denote the amount of extreme events in each class. Blue numbers at the top margin of the figure denote the amount of extreme events in each class.

ecosystem carbon sequestration. Hence, we conclude that an assessment of combinations of extreme climate variables, in particular heat and drought (Zscheischler and Seneviratne, 2017), is indeed crucial for understanding ecosystem impacts (Leonard et al., 2014).

\subsection{Event duration crucially affects extreme-event impacts}

Extreme-event duration is an important factor that influences ecosystem impacts (Frank et al., 2015). In our study, with increasing duration of the extreme climatic event, the impact on GPP generally emerged more clearly (Fig. 4). For $\mathrm{T}_{\max }$ extreme events there was a threshold at a duration of $>27$ days at which GPP strongly decreased by approximately $1-2 \sigma$. This effect was also visible for $\mathrm{R}_{\mathrm{eco}}$, albeit less pronounced. With increasing duration, the response in $\mathrm{R}_{\mathrm{eco}}$ was reversed: for short heat events (i.e., with a duration of less than 18 days), $R_{\text {eco }}$ increased with respect to normal conditions by up to $2 \sigma$, whereas for events that last longer than a month, the response of $\mathrm{R}_{\mathrm{eco}}$ was predominantly negative.

During concurrent $\mathrm{T}_{\max }$ and $\mathrm{WAI}_{\min }$ extremes, GPP and $\mathrm{R}_{\text {eco }}$ were reduced only for extreme events longer than 18 days. For all other extreme types and for the other fluxes, no clear relationship between extreme length and impact was observed (Fig. 4).
The impact of extreme climate events on GPP ranged from a neutral impact (heat lasting less than 1 week, not coinciding with dryness) to severe impacts (if temperature extremes persisted for more than 1 month). The reversal from positive impacts for short durations to negative impacts for long extreme events in the case of $R_{\text {eco }}$ might be interpreted as an initial pulse of microbial activity in the soil, which is reduced after some time when the supply limitation of respiration (i.e., GPP effects) kicks in. Hence, these findings highlight that event duration is a critical parameter that might qualitatively affect the directionality of the response and thus lead to highly nonlinear ecosystem responses. These duration effects are often not explicitly considered in the analysis of climate extreme effects on ecosystems (e.g., Ciais et al., 2005; Wolf et al., 2016). Future research should address the question of whether such nontrivial patterns can be reproduced in model simulations.

Most climate extreme indices for temperature consider only relatively short temperature extremes, such as monthly maximum values of temperature or the count or percentage of days that exceed an absolute or relative threshold. Furthermore, currently used climate extreme indices are based on univariate metrics (Sillmann et al., 2013a). Our empirical analysis shows that ecosystem impacts of climate extremes critically depend on the duration of an extreme event and the coincidence of several climate variables. Hence, most criti$\mathrm{cal} /$ negative ecosystem impacts are seen on timescales of 2 


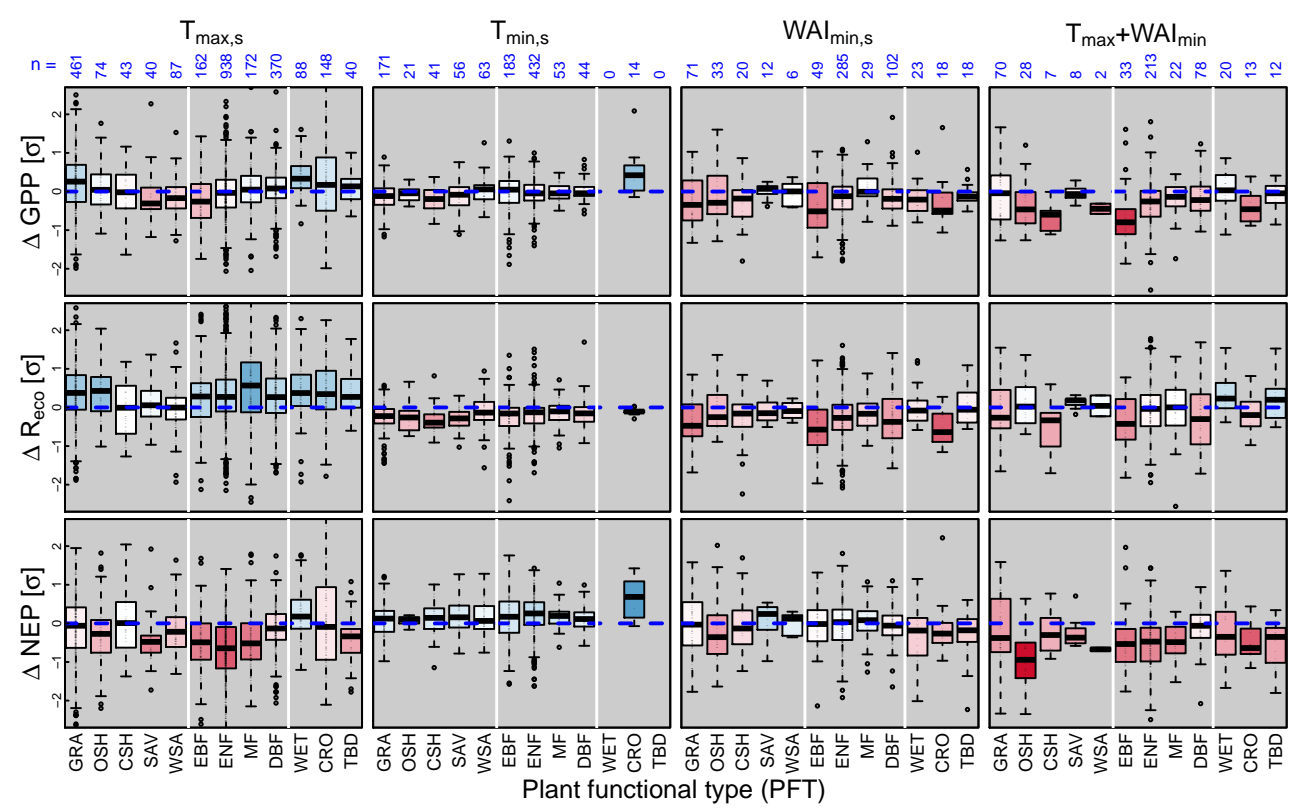

Figure 5. The influence of the ecosystem's plant functional type (PFT) on the extreme-event impact. Shown are the differences between $z$-transformed $\mathrm{CO}_{2}$ fluxes during extreme events and reference periods for the different extreme-event types and the different fluxes $(\Delta z=$ $z_{\text {extr }}-z_{\text {ref }}$; see Eqs. 2 and 3 for details) according to the PFT (see Table A1 for the abbreviations used) of the respective ecosystem (Fig. 4 for a detailed description of the box plots shown).

3 weeks to a few months (see also Murray-Tortarolo et al., 2016) and when heat coincides with dryness.

\subsection{Different impacts in different ecosystems}

Compared to the differences between the means of the impacts discussed above, the spread of the impacts is rather large (Fig. 3). One reason for this is that differences between ecosystems are hidden by the global (i.e., averaged) focus investigated and discussed above. Figure 5 shows the extremeevent impacts for the different extreme-event types separated for the different PFTs, Fig. 6 shows this for different GeigerKöppen climate classes, and Fig. 7 shows this for the combination of the two factors.

The clearest differences between impacts for ecosystems in particular climate zones appeared in the open shrublands (OSH) of the polar climate zone (ET) (Fig. 7). Both GPP and $\mathrm{R}_{\mathrm{eco}}$ were increased by more than $\sim 1 \sigma$ during $\mathrm{T}_{\max }$ extremes (Fig. 6). A stronger increase in GPP led to a slight overall increase in NEP (i.e., a C gain). No drought extremes occurred during the investigated growing seasons in these ecosystems.

A similar but smaller $(\sim 0.3 \sigma)$ GPP increase during heat extremes occurred in the cold arid (BSk), mostly GRA and OSH (Fig. 7), ecosystems (Fig. 6). (For an explanation of ecosystem and climate class abbreviations, please see Tables A1 and A2 in Appendix A.) Here, however, $R_{\text {eco }}$ was increased by a similar magnitude, resulting in only a slight increase in NEP. Again, drought extremes did not occur dur- ing the investigated growing seasons. In contrast, in the warm arid (i.e., BSh climate zone) and exclusively ENF ecosystems, GPP experienced moderate decreases during the $T_{\max }$ extremes. In combination with an increase in $\mathrm{R}_{\mathrm{eco}}$ comparable to the impact in the warm steppe climates (BSh), this resulted in a general NEP decrease.

The ecosystems in the mostly North American and continental European and Asian "snow" climate zones (Dfa, Dfb, $\mathrm{Dfc})$ experienced mean increases in $\mathrm{R}_{\mathrm{eco}}$ during heat extremes of around $0.5 \sigma$ (Fig. 6). GPP, however, showed almost no changes averaged over the whole Dfc (i.e., cold summer) climate zone during heat extremes but with this being the result of a reduction in its open shrublands (OSH) and opposing increases in the wetlands (WET) of this climate zone (Fig. 7). In hot and warm summer ecosystems of this climate zone (Dfa and Dfb), GPP was slightly increased. As a consequence, this resulted in a relatively strong NEP decrease in Dfc ecosystems but only in a moderate decrease in Dfa and Dfb climates. For drought extremes, however, only the summer hot Dfa cropland (CRO) ecosystems showed reductions in $\mathrm{R}_{\mathrm{eco}}$ and, to a lesser extent, in GPP during drought extremes.

Temperate and summer hot and dry (Csa, mainly Mediterranean) ecosystems experienced the strongest GPP reductions $(0.3 \sigma)$, with particularly strong impacts in the forest and savannah ecosystem compared to grasslands and open shrublands (Fig. 7), during heat extremes, whereas $R_{\text {eco }}$ in general was not impacted, resulting in an NEP decrease during heat extremes (Fig. 6). During drought periods, these Csa 


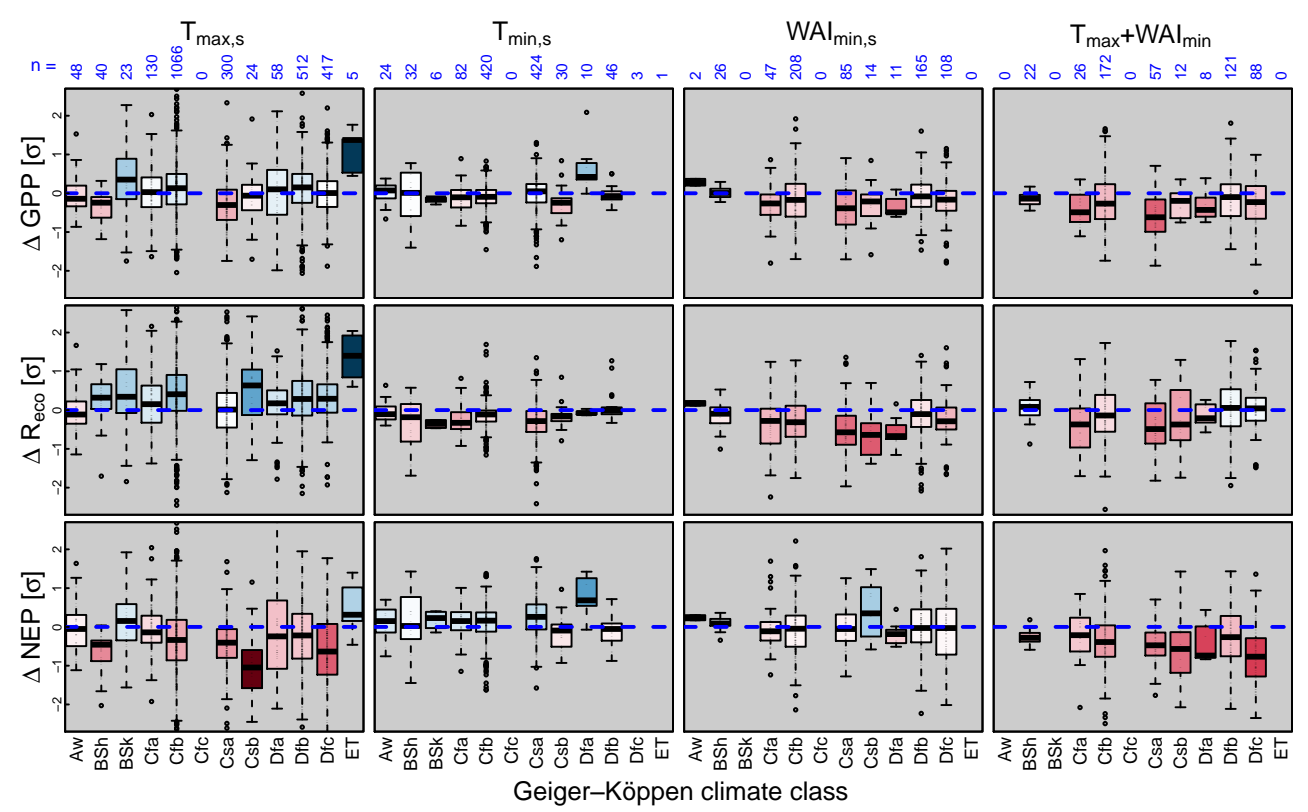

Figure 6. The influence of the ecosystem's ecoclimatic zone on the extreme-event impact. Shown are the differences between $z$-transformed $\mathrm{CO}_{2}$ fluxes during extreme events and reference periods ( $\Delta z=z_{\text {extr }}-z_{\text {ref }}$; see Eqs. 2 and 3 for details) for the different extreme-event types and the different fluxes according to the Geiger-Köppen climate class (Table A2 for the abbreviations used) of the respective ecosystem. (See Fig. 4 for a detailed description of the box plots shown.)

sites were among the ecosystems with the strongest reductions in $\mathrm{R}_{\mathrm{eco}}$ for all forest and savannah ecosystems but not the open shrublands which experienced increases in respiration (Fig. 7) and to a lesser extent in GPP. In contrast, temperate summer dry ecosystems with only warm summers (Csb) did not experience such strong reductions in GPP and even increases in $\mathrm{R}_{\text {eco }}$ during heat extremes and a smaller decrease in GPP during drought extremes (compared to Csa). Most other ecosystems in humid temperate climate zones (Cfa and $\mathrm{Cfb}$ ) showed impacts consistent with the general patterns (i.e slight GPP and stronger $\mathrm{R}_{\mathrm{eco}}$ increases during heat extremes, a reduction in both fluxes during drought and a smaller reduction in $\mathrm{R}_{\mathrm{eco}}$ during concurrent heat and drought) which is in line with other research (i.e., Schwalm et al., 2010; Wolf et al., 2016).

The few equatorial winter dry (Aw) woody savanna ecosystems under investigation experienced slight reductions in GPP during heat extremes. They were one of the few climate zones where $R_{\text {eco }}$ was slightly reduced during $T_{\max }$ extremes. Due to the few sites and short time series, drought extremes did not occur here often enough to reliably investigate their impacts.

Whether temperature or water availability governs an ecosystem's response to extreme events is mainly dependent on whether the ecosystem is located in a temperatureor water-limited environment (Nemani et al., 2003). This explains the strong increases in both GPP and $\mathrm{R}_{\text {eco }}$ during high-temperature extremes in the open shrublands of the temperature-limited polar ET climate zone compared to all other climatic zones (Fig. 8). Similar results have been found by $\mathrm{Wu}$ et al. (2011). In addition, the detected extreme events are at relatively low temperatures below $20^{\circ} \mathrm{C}$, which are probably well below a possible heat stress for the affected plants and still in the range where increasing temperatures increase both GPP rates and the decomposition processes which govern $\mathrm{R}_{\mathrm{eco}}$. An additional factor could have been the increased sunlight during the extreme events (which may have caused the heat extreme in the first place) in these energy-limited regions.

Temperature extremes at sites in the arid steppe climates (BSh and BSk) have comparatively small impacts, probably because most heat extremes occur during dry periods with very low biological activity (Fig. 8). For one BSk site, however, the period of high temperatures and high fluxes coincides with GPP increases during these extreme events, causing the general mean GPP increase in this climate class compared to the BSh sites.

For the one available tropical Aw site, very small seasonal temperature changes between $\approx 30$ and $32{ }^{\circ} \mathrm{C}$ are observed (Fig. 8). As a result, our extreme-detection framework detects all extreme events during the slightly hotter rainy season at the beginning and end of the year (in the Southern Hemisphere). Still, such small temperature differences are unlikely to cause visible physiological impacts, which is demonstrated by the nearly nonexistent mean impact on GPP, $\mathrm{R}_{\text {eco }}$ and NEP in this climate zone. However, station density in tropical ecosystems is very low compared to temperate Northern European or North American sites so this 


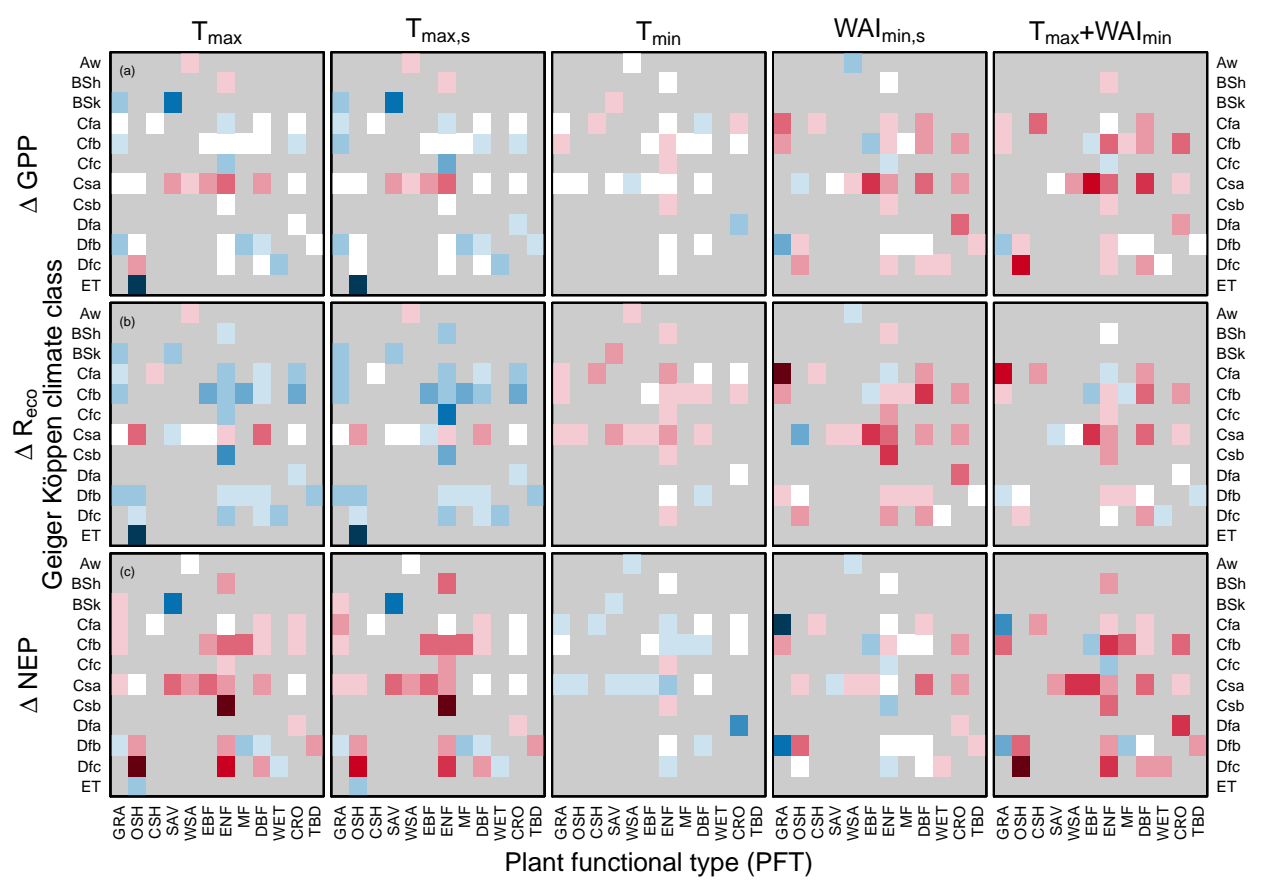

Figure 7. $Z$-transformed flux differences Differences between $z$-transformed $\mathrm{CO}_{2}$ fluxes during extreme events and reference periods for the different extreme-event types and the different fluxes $\left(\Delta z=z_{\text {extr }}-z_{\text {ref }}\right.$; see Eqs. 2 and 3 for details $)$ of the different extreme-event types on GPP, $\mathrm{R}_{\mathrm{eco}}$ and NEP (rows 1-3) separated according to plant functional types (PFT) ( $x$ axis in each plot; see Table A1 for the abbreviations used) and Geiger-Köppen climate class ( $y$ axis in each plot; see Table A2 for the abbreviations used) for different types of extreme events (columns 1-5: heat $\left(\mathrm{T}_{\max }\right)$, heat alone $\left(\mathrm{T}_{\max , \mathrm{s}}\right)$, cold $\left(\mathrm{T}_{\min , \mathrm{s}}\right)$, drought alone $\left(\mathrm{WAI}_{\min , \mathrm{s}}\right)$, and combined heat and drought $\left.\left(\mathrm{T}_{\max }+\mathrm{WAI}_{\min }\right)\right)$. Shades of red indicate reductions of different size in the respective fluxes; shades of blue indicate increases. Refer to Figs. 5 and 6 for a visualization or quantification of the actual magnitude of these impacts.

may also be a consequence of the small amount of extreme events detected.

\subsection{Opportunities and limitations of our approach}

The approach presented in this paper is based on a global, empirical characterization of the impacts of climate extremes on ecosystem-atmosphere carbon fluxes, which has several advantages but also limitations for addressing global ecological questions. Classical extreme-event research has often focused on events where the response was already known a priori to be strong and has possibly neglected several comparable climatic periods with similar conditions but with smaller or even opposite impacts. In contrast, all periods are included in our analysis because we did not select our extreme events a priori. Our results show that comparable extreme events can lead to contrasting impacts, which depend on ecosystem type or extreme-event timing.

In addition, this research is one of the few global and cross-site/ecosystem investigations of extreme climate impacts on (measured) $\mathrm{CO}_{2}$ fluxes. We try to extend the sometimes limiting (but still valuable) focus on particular sites and compare such responses globally. This allows for a holistic picture with which such local site observations can be compared.
Our global results highlight the importance of drought events for the ecosystem carbon cycle. Hence, a reliable estimate of water availability is crucial for the identification of climatic extreme events. As soil water measurements at FLUXNET sites differ strongly between sites in quality, depth and duration, we chose to use the modeled WAI for better between-site comparability and consistency (e.g., Tramontana et al., 2016). Even though we see responses of the fluxes to decreasing WAI, the detailed investigation of individual drought events (e.g., the 2003 heat wave: Fig. 1) highlighted the possible sudden decrease in the fluxes to gradual changes in WAI, emphasizing the need for a reliable estimate of WAI. At this stage, WAI was not optimized for the individual sites and represents a purely hydrometeorological variable rather than a direct measure of ecosystem-specific water stress.

We applied the 95th (or 5th) percentile threshold to define extreme events throughout our study to allow for a comparable extreme definition for all ecosystems. Importantly, this approach has as few a priori assumptions as possible (compared to identifying extreme events via somewhat subjective expert knowledge or by identifying extreme events using extreme responses) and allowed us to thoroughly test such assumptions. However, this approach also has some limita- 


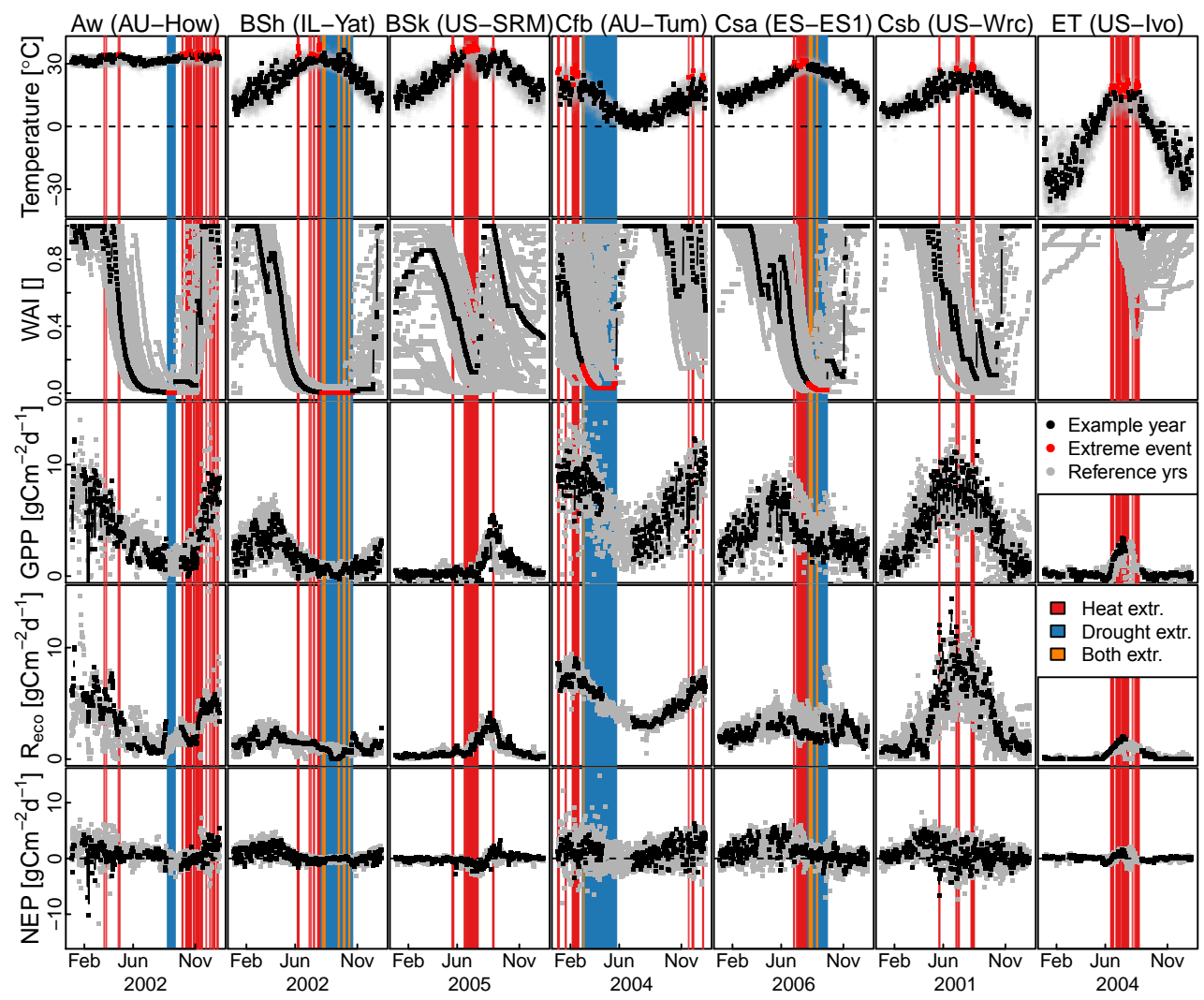

Figure 8. Yearly cycles for climatic forcing variables (air temperature and the water availability index (WAI)) and carbon fluxes (gross primary production (GPP), ecosystem respiration $\left(\mathrm{R}_{\mathrm{eco}}\right.$ ) and net ecosystem production (NEP)) for one example site for each different climatic region (i.e., Geiger-Köppen climate class; see Table A2). One example year (black dots) is shown, with various detected extreme events (red dots). Grey dots represent all reference data from other years. Colored backgrounds indicate the different extreme events detected in the example year.

tions. First, enforcing this extreme definition always leads to a fixed number (i.e., $5 \%$ ) of extreme days per site. For long enough and strongly varying time series, this approach yields actual extreme events. However, for shorter time series or sites with weakly varying climate (e.g., tropical sites), this method may lead to a false positive extreme-event identification of non-extreme conditions. The WAI extreme detection is probably more strongly affected by this problem. For the fairly smooth time series with long periods of low and only slightly varying WAI at several sites (see for example the IT Ro1 WAI time series of 2003 in Fig. 1), this approach probably led to rather arbitrary breaks between extreme and non-extreme time spans caused by only very small WAI differences. A more flexible data-driven approach to determine site-specific extreme thresholds may be helpful for alleviating this problem in future approaches. For WAI in particular, an ecosystem and soil-type-specific threshold may lead to improved results. Finally, future approaches should take additional extreme-strength indicators like amplitude or occurrence into account when defining the extreme threshold. One also has to note that FLUXNET sites are not necessarily well placed to capture extreme events (Mahecha et al., 2017).
We used changes in the $\mathrm{CO}_{2}$ fluxes to quantify the impact of the extreme events. Such changes, however, can only be defined relative to an undisturbed reference period. Due to the strong seasonal cycles at many of the investigated sites, we used fluxes from other years but identical periods (in the year) as these reference values. However, shifts in the phenological cycle between years could bias these reference values, especially during stages of steep phenological changes at the beginning and end of the growing season. We used smoothed data from multiple years to attenuate this effect. A promising future improvement would be to synchronize each yearly cycle with a reference by shifting it in time until a maximum agreement is reached. For short extreme events, the impact could alternatively be calculated with regard to the fluxes before and or after the extreme.

\subsection{Future directions}

In addition to the methodological modifications and improvements outlined above (Sect. 3.5) there are several promising methodological extensions and possibilities. 
For strongly fluctuating time series such as air temperature, our method of defining individual days as extreme and subsequently joining them into concurrent extreme events often resulted in the identification of several successive but interrupted events. These were then analyzed and treated independently, which may neglect their cumulative impact (e.g., Bréda et al., 2006; Granier et al., 2007) on the ecosystem. We alleviated this effect by joining large extreme events with small gaps in between, but our choice of when to join the extreme events and when to treat them separately was rather ad hoc. Such problems could be solved by applying a movingwindow-based approach when detecting the extreme events, which takes into account the "extremeness" of a defined period before each individual day. In particular, this approach could improve the results for the multivariate extreme events where the fluctuations in temperature led to many small, fragmented extreme events.

In addition, our method for defining multivariate extreme events is (intentionally) simple and suffers from some restrictions. By independently identifying extreme events in each climate forcing (i.e., temperature and WAI), we may miss out potentially differing impact thresholds in situations when both forcings are extreme. A true multivariate extremedetection methodology, possibly also including other variables such as vapor pressure deficit or radiation, could overcome this limitation (e.g., Seneviratne et al., 2012; Leonard et al., 2014; Flach et al., 2016; Zscheischler and Seneviratne, 2017).

One important aspect of extreme-event impacts on ecosystems not covered by the approach presented here are lagged or carry-over (i.e., memory) effects (e.g., Krishnan et al., 2006; Bréda et al., 2006; Bigler et al., 2007; Arnone Iii et al., 2008; Thomas et al., 2009). These are impacts which persist even after the end of the actual extreme or occur only after the event or during subsequent growing seasons. In addition, extreme events outside of the growing season (i.e., frost events during winter) are not investigated here. We chose to focus on instantaneous effects and neglect such lagged aspects because only the direct and unambiguous connection of possible impacts to one unique extreme event ensured a large enough sample size to apply the assumption-free approach and test all possible extreme-event sizes and types for impacts. However, focusing on a subset of long and pronounced extreme events, an identical approach could be used to assess non-instantaneous effects. An additional interesting aspect would be to examine the effect of the size of the time span between the extreme-event onset and the flux response for $\mathrm{R}_{\mathrm{eco}}$ and GPP (i.e., the size of the "lag") and a possible difference between the two fluxes (e.g., Zscheischler et al., 2014b).

\section{Conclusions}

In this study we evaluated and corroborated the current understanding and hypotheses about the response of ecosystem $\mathrm{CO}_{2}$ fluxes to extreme climatic events. We aimed for a strictly data-driven and assumption-free approach that takes into account both the extremeness of the climate forcing and that of the response.

Our approach first defines extreme values in the climate data (i.e., the highest and lowest $5 \%$ ) to detect extreme events of varying length and then calculates the difference between $\mathrm{CO}_{2}$ fluxes during these events compared to nonextreme reference periods.

We found that periods of dryness (without extraordinary heat) reduce both GPP and $\mathrm{R}_{\mathrm{eco}}$, which led to a relatively neutral across-site impact in net ecosystem carbon sequestration. In contrast, heat without dryness increased $R_{\text {eco }}$ but did not consistently affect GPP (partly because of differentiated effects across ecosystem types and event duration), which overall led to a reduction in NEP. If heat coincided with drought, these events strongly reduced GPP but yielded smaller reductions in $\mathrm{R}_{\mathrm{eco}}$, which led to strong reductions in NEP. A crucial contributing factor to these differentiated impacts was the duration of the respective climate extreme events: for instance, under heat extremes, $R_{\text {eco }}$ initially increased (for the first 18 days on average) relative to nonextreme conditions but decreased for longer events, presumably due to a reduction in GPP and thus in soil carbon pools for long heat events.

Similar extreme events at similar sites in several cases led to decreases but also to increases in $\mathrm{CO}_{2}$ fluxes, i.e., a large spread remained in the data. These different responses could be partly linked to ecosystem-specific factors. For example, boreal ecosystems experienced strong increases in GPP and $\mathrm{R}_{\mathrm{eco}}$ during heat extremes compared to smaller changes in most other ecosystems, whereas Mediterranean summer dry ecosystems showed particularly strong flux decreases during drought extremes. However, uncertainties and somewhat diverging impacts still remain unexplained after accounting for ecosystem type, climate zone and event duration.

The framework proposed here forms a suitable basis for several promising modifications and more in-depth analyses in the future. We plan to address these open questions by improving the extreme-detection methodology and performing an in-depth investigation of several additional aspects. As responses to heat and drought also influence the exchange of water and, hence, the fluxes of water and energy (e.g., Bonan, 2015) and such fluxes are also measured by the eddy covariance technique (i.e., their net balance), we plan to conduct a similar analysis with these fluxes, as has been done for individual events (e.g., Teuling et al., 2010). Other important aspects to include in future studies are the timing of the extreme during the growing season, which can significantly influence the response (Schwalm et al., 2010; De Boeck and Verbeeck, 2011; Wolf et al., 2013). Eddy covariance mea- 
surements continue to be collected, so for several FLUXNET sites increasingly long time series are becoming available. Hence, we are looking forward to future data releases and to the possibility of extreme-event detection using the measured data directly, without the constraints and possible biases of the downscaling, which highlights the crucial importance of continuous long-term measurements for meaningful ecosystem and climate research.
Data availability. Only third-party data were used as a basis for our calculations. All eddy covariance site data are individually referenced in Table A3. These data were accessed via FLXUNET www.fluxdata.org/DataInfo/default.aspx, and additional site years came from the European Fluxes Database Cluster at www. europe-fluxdata.eu. These data can be downloaded and used after registration according to the data usage policy. ERA-Interim data are provided by the ECMWF and can be downloaded at https://www.ecmwf.int/en/forecasts/datasets/reanalysis-datasets/ era-interim. 


\section{Appendix A}

Table A1. Description of the plant functional type (PFT) classes of the ecosystems investigated in this study (according to the IGBP (International Geosphere-Biosphere Programme) vegetation classification scheme).

\begin{tabular}{lll}
\hline Class & Name & Detailed description \\
\hline CRO & croplands & temporary crops \\
CSH & closed shrublands & woody shrub vegetation \\
DBF & deciduous broadleaf forests & seasonal broadleaf trees \\
EBF & evergreen broadleaf forests & evergreen broadleaf trees \\
ENF & evergreen needleleaf forests & evergreen needleleaf trees \\
GRA & grasslands & herbaceous types (tree and shrub cover $<10 \%)$ \\
MF & mixed forests & mixture of all tree types \\
OSH & open shrublands & woody vegetation $($ cover between 10 and $60 \%)$ \\
SAV & savannas & herbaceous and other understory systems (woodland between 10 and $30 \%$ ). \\
WET & permanent wetlands & permanent mixture of water and herbaceous or woody vegetation \\
WSA & woody savannas & herbaceous/other understory vegetation (woodland between 30 and $60 \%)$ \\
\hline
\end{tabular}

Table A2. Description of Geiger-Köppen climate classes after Kottek et al. (2006) defined by temperature (T) and precipitation (P) (with $\mathrm{P}_{\text {th }}$ being a dryness threshold and subscripted s and w denoting summer and winter values, respectively; see Kottek et al., 2006, for details).

\begin{tabular}{|c|c|c|}
\hline Class & Description & Characteristics \\
\hline A & equatorial climate & $\mathrm{T}_{\min } \geq 18^{\circ} \mathrm{C}$ \\
\hline Af & equatorial fully humid rainforest & $\mathrm{P}_{\min }>60 \mathrm{~mm}$ \\
\hline $\mathrm{Am}$ & equatorial monsoon & $\mathrm{P}_{\mathrm{ann}} \geq 25\left(100 \mathrm{~mm}-\mathrm{P}_{\min }\right)$ \\
\hline As & equatorial savannah + dry summer & $\mathrm{P}_{\min }<60 \mathrm{~mm}$ in summer \\
\hline Aw & equatorial savannah + dry winter & $\mathrm{P}_{\min }<60 \mathrm{~mm}$ in winter \\
\hline B & arid climate & $\mathrm{P}_{\text {ann }}<10 \mathrm{P}_{\text {th }}$ \\
\hline BS & steppe climate & $\mathrm{P}_{\mathrm{ann}}>5 \mathrm{P}_{\mathrm{th}}$ \\
\hline $\mathrm{BW}$ & desert climate & $\mathrm{P}_{\text {ann }} \leq 5 \mathrm{P}_{\text {th }}$ \\
\hline $\mathrm{C}$ & warm temp. climate & $-3^{\circ} \mathrm{C}<\mathrm{T}_{\min }<18^{\circ} \mathrm{C}$ \\
\hline Cs & warm temp. climate + dry sum. & $\mathrm{P}_{\min , \mathrm{s}}<\mathrm{P}_{\min } ; \mathrm{P}_{\max , \mathrm{w}}>3 \mathrm{P}_{\min , \mathrm{s}}$ and $\mathrm{P}_{\min , \mathrm{s}}<40 \mathrm{~mm}$ \\
\hline $\mathrm{Cw}$ & warm temp. climate + dry win. & $\mathrm{P}_{\min , \mathrm{w}}<\mathrm{P}_{\min , \mathrm{s}}$ and $\mathrm{P}_{\max , \mathrm{s}}>10 \mathrm{P}_{\min , \mathrm{w}}$ \\
\hline $\mathrm{Cf}$ & warm temp. fully humid & climate neither $\mathrm{Cs}$ nor $\mathrm{Cw}$ \\
\hline $\mathrm{D}$ & snow climate & $\mathrm{T}_{\min } \leq-3{ }^{\circ} \mathrm{C}$ \\
\hline Ds & snow climate + dry summer & $\mathrm{P}_{\min , \mathrm{s}}<\mathrm{P}_{\min , \mathrm{w}} ; \mathrm{P}_{\max , \mathrm{w}}>3 \mathrm{P}_{\min , \mathrm{s}}$ and $\mathrm{P}_{\min , \mathrm{s}}<40 \mathrm{~mm}$ \\
\hline Dw & snow climate + dry winter & $\mathrm{P}_{\min , \mathrm{w}}<\mathrm{P}_{\min , \mathrm{s}}$ and $\mathrm{P}_{\max , \mathrm{s}}>10 \mathrm{P}_{\min , \mathrm{w}}$ \\
\hline Df & snow climate, fully humid & neither Ds nor Dw \\
\hline $\mathrm{E}$ & polar climate & $\mathrm{T}_{\max } \leq 10^{\circ} \mathrm{C}$ \\
\hline $\mathrm{EF}$ & tundra climate & $0^{\circ} \mathrm{C} \leq \mathrm{T}_{\max }<10^{\circ} \mathrm{C}$ \\
\hline ET & frost climate & $\mathrm{T}_{\max } \leq 0{ }^{\circ} \mathrm{C}$ \\
\hline \multicolumn{3}{|c|}{ Third letter } \\
\hline h & hot steppe/desert & $\mathrm{T}_{\mathrm{ann}} \geq 18^{\circ} \mathrm{C}$ \\
\hline $\mathrm{k}$ & cold steppe/desert & $\mathrm{T}_{\mathrm{ann}}<18^{\circ} \mathrm{C}$ \\
\hline $\mathrm{a}$ & hot summer & $\mathrm{T}_{\max } \geq 22^{\circ} \mathrm{C}$ \\
\hline $\mathrm{b}$ & warm summer & $\operatorname{not}(\mathrm{a})+>4 \mathrm{~T}_{\text {mon }} \geq 10^{\circ} \mathrm{C}$ \\
\hline c & cool summer and cold winter & not (b) and $\mathrm{T}_{\min }>-38^{\circ} \mathrm{C}$ \\
\hline $\mathrm{d}$ & extremely continental & like (c) but $\mathrm{T}_{\min } \leq-38^{\circ} \mathrm{C}$ \\
\hline
\end{tabular}


Table A3. List of FLUXNET sites used in this analysis with their code, name, country, geographical location, Geiger-Köppen climate class (GKC), plant functional type (PFT) and the measurement time periods of the data used.

\begin{tabular}{|c|c|c|c|c|c|c|c|c|}
\hline Code & Name & Country & Latitude & Longitude & PFT & GKC & Site years & Reference \\
\hline AU-How & Howard Springs & Australia & -12.49 & 131.15 & WSA & Aw & $2001-2006$ & Beringer (2003) \\
\hline AU-Tum & Tumbarumba & Australia & -35.66 & 148.15 & EBF & $\mathrm{Cfb}$ & 2001-2006 & $\begin{array}{l}\text { Finnigan and Leuning } \\
\text { (2000) }\end{array}$ \\
\hline BE-Bra & Brasschaat (De Inslag Forest) & Belgium & 51.31 & 4.52 & MF & $\mathrm{Cfb}$ & 1999-2009 & Carrara et al. (2004) \\
\hline BE-Lon & Lonzée & Belgium & 50.55 & 4.74 & $\mathrm{CRO}$ & $\mathrm{Cfb}$ & 2004-2010 & Moureaux et al. (2006) \\
\hline BE-Vie & Vielsalm & Belgium & 50.31 & 6.00 & MF & $\mathrm{Cfb}$ & 1996-2011 & Aubinet et al. (2001) \\
\hline CA-Ca1 & $\begin{array}{l}\text { Campbell River - mature forest } \\
\text { site }\end{array}$ & Canada & 49.87 & -125.33 & ENF & $\mathrm{Cfb}$ & $1997-2005$ & $\begin{array}{l}\text { Morgenstern et al. } \\
(2004)\end{array}$ \\
\hline CA-Let & Lethbridge & Canada & 49.71 & -112.94 & GRA & $\mathrm{Dfb}$ & 1998-2005 & Flanagan et al. (2002) \\
\hline CA-Man & $\begin{array}{l}\text { BOREAS NSA - old black } \\
\text { spruce }\end{array}$ & Canada & 55.88 & -98.48 & ENF & Dfc & $1994-2003$ & Lafleur et al. (2003) \\
\hline CA-Mer & Eastern peatland - Mer Bleue & Canada & 45.41 & -75.52 & WET & Dfb & 1998-2005 & Lafleur et al. (2003) \\
\hline CA-NS2 & UCI-1930 burn site & Canada & 55.91 & -98.52 & ENF & Dfc & 2001-2005 & Goulden et al. (2006) \\
\hline CA-NS3 & UCI-1964 burn site & Canada & 55.91 & -98.38 & ENF & Dfc & 2001-2005 & Goulden et al. (2006) \\
\hline CA-NS6 & UCI-1989 burn site & Canada & 55.92 & -98.96 & $\mathrm{OSH}$ & Dfc & 2001-2005 & Goulden et al. (2006) \\
\hline CA-Oas & Sask.-SSA old aspen & Canada & 53.63 & -106.20 & DBF & Dfc & 1997-2005 & Black et al. (1996) \\
\hline CA-Obs & Sask.-SSA old black spruce & Canada & 53.99 & -105.12 & ENF & Dfc & 1999-2005 & Jarvis et al. (1997) \\
\hline CA-Ojp & Sask.-SSA old jack pine & Canada & 53.92 & -104.69 & ENF & Dfc & 1999-2005 & Baldocchi et al. (1997) \\
\hline CA-Qfo & Québec mature boreal forest site & Canada & 49.69 & -74.34 & ENF & Dfc & 2003-2006 & Bergeron et al. (2007) \\
\hline $\mathrm{CH}-\mathrm{Oe} 1$ & Oensingen 1 grass & Switzerland & 47.29 & 7.73 & GRA & $\mathrm{Cfb}$ & 2002-2008 & Ammann et al. (2007) \\
\hline CZ-BK1 & Bílý Kř́ǐ̌ - Beskid Mountains & $\begin{array}{l}\text { Czech } \\
\text { Republic }\end{array}$ & 49.50 & 18.54 & ENF & Dfb & $2000-2012$ & $\begin{array}{l}\text { Havránková and Sedlák } \\
\text { (2004) }\end{array}$ \\
\hline CZ-BK2 & Bílý Kř́ǐz - grassland & $\begin{array}{l}\text { Czech } \\
\text { Republic }\end{array}$ & 49.50 & 18.54 & GRA & $\mathrm{Dfb}$ & 2004-2011 & Marek et al. (2011) \\
\hline DE-Geb & Gebesee & Germany & 51.10 & 10.91 & $\mathrm{CRO}$ & $\mathrm{Cfb}$ & 2002-2008 & Anthoni et al. (2004) \\
\hline DE-Hai & Hainich & Germany & 51.08 & 10.45 & DBF & $\mathrm{Cfb}$ & $2000-2007$ & Knohl et al. (2003) \\
\hline DE-Wet & Wetzstein & Germany & 50.45 & 11.46 & ENF & $\mathrm{Cfb}$ & $2005-2008$ & Anthoni et al. (2004) \\
\hline DK-Sor & Sor $\varnothing-$ Lille Bogeskov & Denmark & 55.49 & 11.65 & $\mathrm{DBF}$ & $\mathrm{Cfb}$ & 1996-2009 & Pilegaard et al. (2001) \\
\hline ES-ES1 & El Saler & Spain & 39.35 & -0.32 & ENF & Csa & 1999-2006 & Reichstein et al. (2005) \\
\hline ES-LMa & Las Majadas del Tiétar & Spain & 39.94 & -5.77 & SAV & Csa & 2004-2011 & $\begin{array}{l}\text { Perez-Priego et al. } \\
(2017)\end{array}$ \\
\hline FI-Kaa & Kaamanen wetland & Finland & 69.14 & 27.30 & WET & Dfc & 2000-2008 & Aurela et al. (2004) \\
\hline FI-Sod & Sodankylä & Finland & 67.36 & 26.64 & ENF & Dfc & 2000-2008 & Thum et al. (2007) \\
\hline FR-Fon & Fontainebleau & France & 48.48 & 2.78 & DBF & $\mathrm{Cfb}$ & $2005-2008$ & Michelot et al. (2011) \\
\hline FR-LBr & Le Bray (after 28 Jun 1998) & France & 44.72 & -0.77 & ENF & $\mathrm{Cfb}$ & 1996-2008 & Berbigier et al. (2001) \\
\hline FR-Lq1 & Laqueuille & France & 45.64 & 2.74 & GRA & $\mathrm{Cfb}$ & $2004-2010$ & Allard et al. (2007) \\
\hline FR-Lq2 & Laqueuille extensive & France & 45.64 & 2.74 & GRA & $\mathrm{Cfb}$ & 2004-2010 & Allard et al. (2007) \\
\hline FR-Pue & Puéchabon & France & 43.74 & 3.60 & $\mathrm{EBF}$ & Csa & 2000-2011 & Rambal et al. (2004) \\
\hline HU-Bug & Bugac puszta & Hungary & 46.69 & 19.60 & GRA & $\mathrm{Cfb}$ & 2002-2008 & Nagy et al. (2007) \\
\hline HU-Mat & Mátra & Hungary & 47.85 & 19.73 & GRA & $\mathrm{Cfb}$ & $2004-2008$ & Nagy et al. (2007) \\
\hline IE-Dri & Dripsey & Ireland & 51.99 & -8.75 & GRA & $\mathrm{Cfb}$ & $2003-2007$ & Peichl et al. (2011) \\
\hline IL-Yat & Yatir & Israel & 31.34 & 35.05 & ENF & $\mathrm{BSh}$ & 2001-2006 & Grünzweig et al. (2003) \\
\hline IT-Amp & Amplero & Italy & 41.90 & 13.61 & GRA & $\mathrm{Cfa}$ & 2002-2008 & Wohlfahrt et al. (2008) \\
\hline IT-Cpz & Castelporziano & Italy & 41.71 & 12.38 & $\mathrm{EBF}$ & Csa & 1997-2008 & Tirone et al. (2003) \\
\hline IT-Lav & Lavarone (after Mar 2002) & Italy & 45.96 & 11.28 & ENF & $\mathrm{Cfb}$ & $2000-2012$ & $\begin{array}{l}\text { Cescatti and Marcolla } \\
\text { (2004) }\end{array}$ \\
\hline IT-LMa & La Mandria & Italy & 45.58 & 7.15 & GRA & $\mathrm{Cfb}$ & 2003-2009 & Maselli et al. (2006) \\
\hline IT-MBo & Monte Bondone & Italy & 46.02 & 11.05 & GRA & $\mathrm{Cfb}$ & 2003-2012 & $\begin{array}{l}\text { Marcolla and Cescatti } \\
\text { (2005) }\end{array}$ \\
\hline IT-Non & Nonantola & Italy & 44.69 & 11.09 & DBF & $\mathrm{Cfa}$ & 2001-2008 & Nardino et al. (2002) \\
\hline IT-Pia & Island of Pianosa & Italy & 42.58 & 10.08 & OSH & Csa & 2002-2006 & Vaccari et al. (2012) \\
\hline IT-SRo & San Rossore & Italy & 43.73 & 10.28 & ENF & Csa & 1999-2010 & Chiesi et al. (2005) \\
\hline JP-Tak & Takayama & Japan & 36.15 & 137.42 & DBF & $\mathrm{Dfb}$ & 1999-2004 & Yamamoto et al. (1999) \\
\hline JP-Tom & Tomakomai National Forest & Japan & 42.74 & 141.51 & MF & Dfb & 2001-2003 & Hirano et al. (2003) \\
\hline NL-Hor & Horstermeer & Netherlands & 52.03 & 5.07 & GRA & $\mathrm{Cfb}$ & $2004-2010$ & Hendriks et al. (2007) \\
\hline NL-Loo & Loobos & Netherlands & 52.17 & 5.74 & ENF & $\mathrm{Cfb}$ & $1996-2012$ & Dolman et al. (2002) \\
\hline PT-Esp & Espirra & Portugal & 38.64 & -8.60 & EBF & Csa & $2002-2008$ & Rodrigues et al. (2011) \\
\hline PT-Mi2 & Mitra IV Tojal & Portugal & 38.48 & -8.02 & GRA & Csa & 2004-2008 & Pereira et al. (2007) \\
\hline RU-Fyo & Fyodorovskoye wet spruce stand & Russia & 56.46 & 32.92 & ENF & $\mathrm{Dfb}$ & $1998-2010$ & Kurbatova et al. (2008) \\
\hline
\end{tabular}


Table A3. Continued.

\begin{tabular}{|c|c|c|c|c|c|c|c|c|}
\hline Code & Name & Country & Latitude & Longitude & PFT & GKC & Site years & Reference \\
\hline SE-Deg & Degerö & Sweden & 64.18 & 19.55 & WET & Dfc & 2001-2009 & Sagerfors et al. (2008) \\
\hline SE-Fla & Flakaliden & Sweden & 64.11 & 19.46 & ENF & Dfc & 1996-2002 & Valentini et al. (2000) \\
\hline SE-Nor & Norunda & Sweden & 60.09 & 17.48 & ENF & $\mathrm{Dfb}$ & 1996-2007 & Lagergren et al. (2008) \\
\hline US-Bo1 & IL - Bondville & USA & 40.01 & -88.29 & $\mathrm{CRO}$ & Dfa & 1996-2007 & $\begin{array}{l}\text { Meyers and Hollinger } \\
(2004)\end{array}$ \\
\hline US-FPe & MT - Fort Peck & USA & 48.31 & -105.10 & GRA & BSk & $2000-2006$ & Pataki and Oren (2003) \\
\hline US-Ho1 & $\begin{array}{l}\text { ME - Howland Forest (main } \\
\text { tower) }\end{array}$ & USA & 45.20 & -68.74 & ENF & Dfb & $1996-2004$ & Hollinger et al. (2004) \\
\hline US-Ho2 & $\begin{array}{l}\text { ME - Howland Forest (west } \\
\text { tower) }\end{array}$ & USA & 45.21 & -68.75 & ENF & Dfb & 1999-2004 & Hollinger et al. (2004) \\
\hline US-Ivo & AK - Ivotuk & USA & 68.49 & -155.75 & WET & ET & $2003-2006$ & Epstein et al. (2004) \\
\hline US-KS2 & FL - Kennedy Space Center & USA & 28.61 & -80.67 & $\mathrm{CSH}$ & $\mathrm{Cfa}$ & $2000-2006$ & Powell et al. (2006) \\
\hline US-MMS & $\begin{array}{l}\text { IN - Morgan Monroe State For- } \\
\text { est }\end{array}$ & USA & 39.32 & -86.41 & $\mathrm{DBF}$ & $\mathrm{Cfa}$ & $1999-2005$ & Roman et al. (2015) \\
\hline US-NR1 & $\mathrm{CO}$ - Niwot Ridge Forest & USA & 40.03 & -105.55 & ENF & Dfc & 1999-2003 & Monson et al. (2002) \\
\hline US-SO4 & CA - Sky Oaks - New Stand & USA & 33.38 & -116.64 & $\mathrm{CSH}$ & Csa & 2004-2006 & Lipson et al. (2005) \\
\hline US-SRM & AZ - Santa Rita Mesquite & USA & 31.82 & -110.87 & WSA & BSk & 2004-2006 & Scott et al. (2009) \\
\hline US-Ton & CA - Tonzi Ranch & USA & 38.43 & -120.97 & WSA & Csa & 2001-2006 & Ma et al. (2007) \\
\hline US-UMB & $\begin{array}{l}\text { MI - Univ. of Mich. Biological } \\
\text { Station }\end{array}$ & USA & 45.56 & -84.71 & DBF & Dfb & 1999-2003 & Gough et al. (2008) \\
\hline US-Var & CA - Vaira Ranch - Ione & USA & 38.41 & -120.95 & GRA & Csa & 2001-2006 & $\begin{array}{l}\mathrm{Xu} \text { and Baldocchi } \\
(2004)\end{array}$ \\
\hline US-WCr & WI - Willow Creek & USA & 45.81 & -90.08 & $\mathrm{DBF}$ & Dfb & 1999-2006 & Cook et al. (2004) \\
\hline US-Wrc & WA - Wind River Crane Site & USA & 45.82 & -121.95 & ENF & $\mathrm{Csb}$ & 1998-2006 & Falk et al. (2008) \\
\hline
\end{tabular}


Competing interests. The authors declare that they have no conflict of interest.

Acknowledgements. Authors affiliated with the MPI for Biogeochemistry acknowledge the European Union for funding via the H2020 project BACI (grant agreement no.: 640176). This work used eddy covariance data acquired by the FLUXNET community and in particular by the following networks: AmeriFlux (US Department of Energy, Biological and Environmental Research, Terrestrial Carbon Program (DE-FG02-04ER63917 and DE-FG020-4ER63911)), AfriFlux, AsiaFlux, CarboAfrica, CarboEuropeIP, CarboItaly, CarboMont, ChinaFlux, Fluxnet-Canada (supported by CFCAS, NSERC, BIOCAP, Environment Canada and NRCan), Canadian Carbon Program (supported by CFCAS, Environment Canada and NRCan), GreenGrass, KoFlux, LBA, NECC, OzFlux, Swiss FluxNet, TCOS-Siberia and USCCC. We acknowledge the financial support for the eddy covariance data harmonization provided by CarboEuropeIP, FAO-GTOS-TCO, iLEAPS, the Max Planck Institute for Biogeochemistry, the National Science Foundation, the University of Tuscia, Universite Laval, Environment Canada and the US Department of Energy; we also acknowledge the database development and technical support from Berkeley Water Center, Lawrence Berkeley National Laboratory, Microsoft Research eScience, Oak Ridge National Laboratory, University of California - Berkeley and the University of Virginia. Finally we thank Andrew Durso for helpful comments and assistance on the fine secrets of the English language.

The article processing charges for this open-access publication were covered by the Max Planck Society.

Edited by: David Bowling

Reviewed by: two anonymous referees

\section{References}

Allakhverdiev, S. I., Kreslavski, V. D., Klimov, V. V., Los, D. A., Carpentier, R., and Mohanty, P.: Heat stress: an overview of molecular responses in photosynthesis, Photosynth. Res., 98, 541-550, https://doi.org/10.1007/s11120-008-9331-0, 2008.

Allard, V., Soussana, J.-F., Falcimagne, R., Berbigier, P., Bonnefond, J.-M., Ceschia, E., D’hour, P., Hánault, C., Laville, P., Martin, C., and Pinarès-Patino, C.: The role of grazing management for the net biome productivity and greenhouse gas budget $\left(\mathrm{CO}_{2}\right.$, $\mathrm{N}_{2} \mathrm{O}$ and $\mathrm{CH}_{4}$ ) of semi-natural grassland, Agr. Ecosyst. Environ., 121, 47-58, 2007.

Ammann, C., Flechard, C. R., Leifeld, J., Neftel, A., and Fuhrer, J.: The carbon budget of newly established temperate grassland depends on management intensity, Agr. Ecosyst. Environ., 121, 5-20, 2007.

Anderson-Teixeira, K. J., Delong, J. P., Fox, A. M., Brese, D. A., and Litvak, M. E.: Differential responses of production and respiration to temperature and moisture drive the carbon balance across a climatic gradient in New Mexico, Glob. Change Biol., 17, 410-424, https://doi.org/10.1111/j.1365-2486.2010.02269.x, 2011.
Anthoni, P. M., Knohl, A., Rebmann, C., Freibauer, A., Mund, M., Ziegler, W., Kolle, O., and Schulze, E.-D.: Forest and agricultural land-use-dependent $\mathrm{CO}_{2}$ exchange in Thuringia, Germany, Glob. Change Biol., 10, 2005-2019, 2004.

Arnone Iii, J. A., Verburg, P. S. J., Johnson, D. W., Larsen, J. D., Jasoni, R. L., Lucchesi, A. J., Batts, C. M., von Nagy, C., Coulombe, W. G., Schorran, D. E., Buck, P. E., Braswell, B. H., Coleman, J. S., Sherry, R. A., Wallace, L. L., Luo, Y., and Schimel, D. S.: Prolonged suppression of ecosystem carbon dioxide uptake after an anomalously warm year, Nature, 455, 383-386, https://doi.org/10.1038/nature07296, 2008.

Aubinet, M., Chermanne, B., Vandenhaute, M., Longdoz, B., Yernaux, M., and Laitat, E.: Long term carbon dioxide exchange above a mixed forest in the Belgian Ardennes, Agr. Forest Meteorol., 108, 293-315, 2001.

Aurela, M., Laurila, T., and Tuovinen, J.-P.: The timing of snow melt controls the annual $\mathrm{CO}_{2}$ balance in a subarctic fen, Geophys. Res. Lett., 31, L16119, https://doi.org/10.1029/2004GL020315, 2004.

Baldocchi, D.: "Breathing" of the terrestrial biosphere: lessons learned from a global network of carbon dioxide flux measurement systems, Aust. J. Bot., 56, 1-26, https://doi.org/10.1071/BT07151, 2008.

Baldocchi, D.: Measuring fluxes of trace gases and energy between ecosystems and the atmosphere - the state and future of the eddy covariance method, Glob. Change Biol., 20, 3600-3609, 2014.

Baldocchi, D., Falge, E., Gu, L. H., Olson, R., Hollinger, D., Running, S., Anthoni, P., Bernhofer, C., Davis, K., Evans, R., Fuentes, J., Goldstein, A., Katul, G., Law, B., Lee, X. H., Malhi, Y., Meyers, T., Munger, W., Oechel, W., Paw U, K. T., Pilegaard, K., Schmid, H. P., Valentini, R., Verma, S., Vesala, T., Wilson, K., and Wofsy, S.: FLUXNET: a new tool to study the temporal and spatial variability of ecosystem-scale carbon dioxide, water vapor, and energy flux densities, B. Am. Meteorol. Soc., 82, 2415-2434, 2001.

Baldocchi, D. D.: Assessing the Eddy Covariance technique for evaluating carbon dioxide exchange rates of ecosystems: past, present and future, Glob. Change Biol., 9, 479-492, https://doi.org/10.1046/j.1365-2486.2003.00629.x, 2003.

Baldocchi, D. D., Vogel, C. A., and Hall, B.: Seasonal variation of carbon dioxide exchange rates above and below a boreal jack pine forest, Agr. Forest Meteorol., 83, 147-170, 1997.

Beer, C., Reichstein, M., Tomelleri, E., Ciais, P., Jung, M., Carvalhais, N., Rödenbeck, C., Arain, M. A., Baldocchi, D., Bonan, G. B., Bondeau, A., Cescatti, A., Lasslop, G., Lindroth, A., Lomas, M., Luyssaert, S., Margolis, H., Oleson, K. W., Roupsard, O., Veenendaal, E., Viovy, N., Williams, C., Woodward, F. I., and Papale, D.: Terrestrial gross carbon dioxide uptake: global distribution and covariation with climate, Science, 329, 834-838, 2010.

Berbigier, P., Bonnefond, J.-M., and Mellmann, P.: $\mathrm{CO}_{2}$ and water vapour fluxes for 2 years above Euroflux forest site, Agr. Forest Meteorol., 108, 183-197, 2001.

Bergeron, O., Margolis, H. A., Black, T. A., Coursolle, C., Dunn, A. L., Barr, A. G., and Wofsy, S. C.: Comparison of carbon dioxide fluxes over three boreal black spruce forests in Canada, Glob. Change Biol., 13, 89-107, 2007. 
Beringer: Fire impacts on surface heat, moisture and carbon fluxes from a tropical savanna in northern Australia, Int. J. Wildland Fire, 12, 333-340, https://doi.org/10.1071/WF03023, 2003.

Bernacchi, C. J., Singsaas, E. L., Pimentel, C., Portis Jr., A. R., and Long, S. P.: Improved temperature response functions for models of Rubisco-limited photosynthesis, Plant Cell Environ., 24, 253259, 2001.

Bigler, C., Gavin, D. G., Gunning, C., and Veblen, T. T.: Drought induces lagged tree mortality in a subalpine forest in the Rocky Mountains, Oikos, 116, 1983-1994, 2007.

Black, T. A., Hartog, G., Neumann, H. H., Blanken, P. D., Yang, P. C., Russell, C., Nesic, Z., Lee, X., Chen, S. G., Staebler, R., and Novak, M. D.: Annual cycles of water vapour and carbon dioxide fluxes in and above a boreal aspen forest, Glob. Change Biol., 2, 219-229, 1996.

Bloor, J. M. and Bardgett, R. D.: Stability of above-ground and below-ground processes to extreme drought in model grassland ecosystems: interactions with plant species diversity and soil nitrogen availability, Perspect. Plant Ecol., 14, 193-204, 2012.

Bonan, G.: Ecological Climatology: Concepts and Applications, Cambridge University Press, Cambridge, New York, USA, 2015.

Bonan, G. B.: Forests and climate change: Forcings, feedbacks, and the climate benefits of forests, Science, 320, 1444-1449, https://doi.org/10.1126/science.1155121, 2008.

Bréda, N., Huc, R., Granier, A., and Dreyer, E.: Temperate forest trees and stands under severe drought: a review of ecophysiological responses, adaptation processes and long-term consequences, Ann. For. Sci., 63, 625-644, https://doi.org/10.1051/forest:2006042, 2006.

Canadell, J. G., Mooney, H. A., Baldocchi, D. D., Berry, J. A., Ehleringer, J. R., Field, C. B., Gower, S. T., Hollinger, D. Y., Hunt, J. E., Jackson, R. B., Running, S. W., Shaver, G. R., Steffen, W., Trumbore, S. E., Valentini, R., and Bond, B. Y.: Carbon metabolism of the terrestrial biosphere: a multitechnique approach for improved understanding, Ecosystems, 3, 115-130, 2000.

Carrara, A., Janssens, I. A., Yuste, J. C., and Ceulemans, R.: Seasonal changes in photosynthesis, respiration and NEE of a mixed temperate forest, Agr. Forest Meteorol., 126, 15-31, 2004.

Cescatti, A. and Marcolla, B.: Drag coefficient and turbulence intensity in conifer canopies, Agr. Forest Meteorol., 121, 197-206, 2004.

Chaves, M. M.: Effects of water deficits on carbon assimilation, J. Exp. Bot., 42, 1-16, 1991.

Chaves, M. M., Flexas, J., and Pinheiro, C.: Photosynthesis under drought and salt stress: regulation mechanisms from whole plant to cell, Ann. Bot., 103, 551-560, https://doi.org/10.1093/aob/mcn125, 2009.

Chiesi, M., Maselli, F., Bindi, M., Fibbi, L., Cherubini, P., Arlotta, E., Tirone, G., Matteucci, G., and Seufert, G.: Modelling carbon budget of Mediterranean forests using ground and remote sensing measurements, Agr. Forest Meteorol., 135, 22-34, 2005.

Ciais, P., Reichstein, M., Viovy, N., Granier, A., Ogee, J.e, J., Allard, V., Aubinet, M., Buchmann, N., Bernhofer, C., Carrara, A., Chevallier, F., De Noblet, N., Friend, A. D., Friedlingstein, P., Gruenwald, T., Heinesch, B., Keronen, P., Knohl, A., Krinner, G., Loustau, D., Manca, G., Matteucci, G., Miglietta, F., Ourcival, J. M., Papale, D., Pilegaard, K., Rambal, S., Seufert, G., Soussana, J. F., Sanz, M. J., Schulze, E. D., Vesala, T., and Valentini, R.: Europe-wide reduction in primary productivity caused by the heat and drought in 2003, Nature, 437, 529-533, https://doi.org/10.1038/nature03972, 2005.

Cook, B. D., Davis, K. J., Wang, W., Desai, A., Berger, B.W., Teclaw, R. M., Martin, J. G., Bolstad, P. V., Bakwin, P. S., Yi, C., and Heilman, W.: Carbon exchange and venting anomalies in an upland deciduous forest in northern Wisconsin, USA, Agr. Forest Meteorol., 126, 271-295, 2004.

Cramer, W., Kicklighter, D. W., Bondeau, A., Iii, B. M., Churkina, G., Nemry, B., Ruimy, A., Schloss, A. L., and the participants of the Potsdam NPP mode intercomparison: Comparing global models of terrestrial net primary productivity (NPP): overview and key results, Glob. Change Biol., 5, 1-15, https://doi.org/10.1046/j.1365-2486.1999.00009.x, 1999.

Davidson, E. A. and Janssens, I. A.: Temperature sensitivity of soil carbon decomposition and feedbacks to climate change, Nature, 440, 165-173, 2006.

Davidson, E. A., Belk, E., and Boone, R. D.: Soil water content and temperature as independent or confounded factors controlling soil respiration in a temperate mixed hardwood forest, Glob. Change Biol., 4, 217-227, https://doi.org/10.1046/j.13652486.1998.00128.x, 1998.

De Boeck, H. J. and Verbeeck, H.: Drought-associated changes in climate and their relevance for ecosystem experiments and models, Biogeosciences, 8, 1121-1130, https://doi.org/10.5194/bg-81121-2011, 2011.

De Boeck, H. J., Dreesen, F. E., Janssens, I. A., and Nijs, I.: Climatic characteristics of heat waves and their simulation in plant experiments, Glob. Change Biol., 16, 1992-2000, https://doi.org/10.1111/j.1365-2486.2009.02049.x, 2010.

Dee, D. P., Uppala, S. M., Simmons, A. J., Berrisford, P., Poli, P., Kobayashi, S., Andrae, U., Balmaseda, M. A., Balsamo, G., Bauer, P., and Bechtold, P.: The ERA-Interim reanalysis: Configuration and performance of the data assimilation system, Q. J. Roy. Meteorol. Soc., 137, 553-597, 2011.

Dolman, A., Moors, E., and Elbers, J.: The carbon uptake of a mid latitude pine forest growing on sandy soil, Agr. Forest Meteorol., 111, 157-170, 2002.

Epron, D., Ngao, J., and Granier, A.: Interannual variation of soil respiration in a beech forest ecosystem over a six-year study, Ann. Forest Sci., 61, 499-505, https://doi.org/10.1051/forest:2004044, 2004.

Epstein, H. E., Calef, M. P., Walker, M. D., Stuart Chapin, F., and Starfield, A. M.: Detecting changes in arctic tundra plant communities in response to warming over decadal time scales, Glob. Change Biol., 10, 1325-1334, 2004.

Falk, M., Wharton, S., Schroeder, M., Ustin, S., and Paw U, K. T.: Flux partitioning in an old-growth forest: seasonal and interannual dynamics, Tree Physiol., 28, 509-520, 2008.

Farquhar, G. D., Caemmerer, S. V., and Berry, J. A.: A biochemicalmodel of photosynthetic $\mathrm{CO}_{2}$ assimilation in leaves of $\mathrm{C}-3$ species, Planta, 149, 78-90, 1980.

Finnigan, J. and Leuning, R.: Long term flux measurementscoordinate systems and averaging, in: Proc. International Workshop for Advanced Flux Network and Flux Evaluation, 51-56, Centre for Global Environmental Research, National Institute for Environmental Studies, 2000.

Fischer, E. M., Seneviratne, S. I., Lüthi, D., and Schär, C.: Contribution of land-atmosphere coupling to recent Euro- 
pean summer heat waves, Geophys. Res. Lett., 34, L06707, https://doi.org/10.1029/2006GL029068, 2007.

Fisher, R. A., Williams, M., Da Costa, A. L., Malhi, Y., Da Costa, R. F., Almeida, S., and Meir, P.: The response of an Eastern Amazonian rain forest to drought stress: results and modelling analyses from a throughfall exclusion experiment, Glob. Change Biol., 13, 2361-2378, https://doi.org/10.1111/j.13652486.2007.01417.x, 2007.

Flach, M., Gans, F., Brenning, A., Denzler, J., Reichstein, M., Rodner, E., Bathiany, S., Bodesheim, P., Guanche, Y., Sippel, S., and Mahecha, M. D.: Multivariate anomaly detection for Earth observations: a comparison of algorithms and feature extraction techniques, Earth Syst. Dynam., 8, 677-696, https://doi.org/10.5194/esd-8-677-2017, 2017.

Flanagan, L. B., Wever, L. A., and Carlson, P. J.: Seasonal and interannual variation in carbon dioxide exchange and carbon balance in a northern temperate grassland, Glob. Change Biol., 8, 599615, https://doi.org/10.1046/j.1365-2486.2002.00491.x, 2002.

Flexas, J. and Medrano, H.: Drought-inhibition of photosynthesis in C-3 plants: Stomatal and non-stomatal limitations revisited, Ann. Bot., 89, 183-189, https://doi.org/10.1093/aob/mcf027, 2002.

Frank, D., Reichstein, M., Bahn, M., Frank, D., Mahecha, M. D., Smith, P., Thonicke, K., van der Velde, M., Vicca, S., Babst, F., Beer, C., Buchmann, N., Canadell, J. G., Ciais, P., Cramer, W., Ibrom, A., Miglietta, F., Poulter, B., Rammig, A., Seneviratne, S. I., Walz, A., Wattenbach, M., Zavala, M. A., and Zscheischler, J.: Effects of climate extremes on the terrestrial carbon cycle: concepts, processes and potential future impacts, Glob. Change Biol., 2, 2861-2880, https://doi.org/10.1111/gcb.12916, 2015.

Friedlingstein, P., Cox, P., Betts, R., Bopp, L., von Bloh, W., Brovkin, V., Cadule, P., Doney, S., Eby, M., Fung, I., Bala, G., John, J., Jones, C., Joos, F., Kato, T., Kawamiya, M., Knorr, W., Lindsay, K., Matthews, H. D., Raddatz, T., Rayner, P., Reick, C., Roeckner, E., Schnitzler, K.-G., Schnur, R., Strassmann, K., Weaver, A. J., Yoshikawa, C., and Zeng, N.: Climate-carbon cycle feedback analysis: Results from the C4MIP model intercomparison, J. Climate, 19, 3337-3353, https://doi.org/10.1175/JCLI3800.1, 2006.

Gaumont-Guay, D., Black, T. A., Griffis, T. J., Barr, A. G., Jassal, R. S., and Nesic, Z.: Interpreting the dependence of soil respiration on soil temperature and water content in a boreal aspen stand, Agricultural and Forest Meteorol., 140, 220-235, https://doi.org/10.1016/j.agrformet.2006.08.003, 2006.

Ghil, M., Yiou, P., Hallegatte, S., Malamud, B. D., Naveau, P., Soloviev, A., Friederichs, P., Keilis-Borok, V., Kondrashov, D., Kossobokov, V., Mestre, O., Nicolis, C., Rust, H. W., Shebalin, P., Vrac, M., Witt, A., and Zaliapin, I.: Extreme events: dynamics, statistics and prediction, Nonlin. Processes Geophys., 18, 295-350, https://doi.org/10.5194/npg-18-295-2011, 2011.

Gough, C., Vogel, C., Schmid, H., Su, H.-B., and Curtis, P.: Multiyear convergence of biometric and meteorological estimates of forest carbon storage, Agr. Forest Meteorol., 148, 158-170, 2008.

Goulden, M. L., Winston, G. C., McMillan, A., Litvak, M. E., Read, E. L., Rocha, A. V., and Rob Elliot, J.: An eddy covariance mesonet to measure the effect of forest age on land-atmosphere exchange, Glob. Change Biol., 12, 2146-2162, 2006.

Granier, A., Reichstein, M., Bréda, N., Janssens, I., Falge, E., Ciais, P., Gruenwaldnwald, T., Aubinet, M., Berbigier, P., Bern- hofer, C., Buchmann, N., Facini, O., Grassi, G., Heinesch, B., Ilvesniemi, H., Keronen, P., Knohl, A., Koestner, B., Lagergren, F., Lindroth, A., Longdoz, B., Loustau, D., Mateus, J., Montagnani, L., Nys, C., Moors, E., Papale, D., Peiffer, M., Pilegaard, K., Pita, G., Pumpanen, J., Rambal, S., Rebmann, C., Rodrigues, A., Seufert, G., Tenhunen, J., Vesala, T., and Wang, Q.: Evidence for soil water control on carbon and water dynamics in European forests during the extremely dry year: 2003, Agr. Forest Meteorol., 143, 123-145, https://doi.org/10.1016/j.agrformet.2006.12.004, 2007.

Green, J. K., Konings, A. G., Alemohammad, S. H., Berry, J., Entekhabi, D., Kolassa, J., Lee, J.-E., and Gentine, P.: Regionally strong feedbacks between the atmosphere and terrestrial biosphere, Nat. Geosci., 10, 410-414, 2017.

Grünzweig, J., Lin, T., Rotenberg, E., Schwartz, A., and Yakir, D.: Carbon sequestration in arid-land forest, Glob. Change Biol., 9, 791-799, 2003.

Havránková, K. and Sedlák, P.: Wind velocity analysis for mountainous site Bily Kriz, Ekologia-Bratislava, 23, 46-54, 2004.

Hendriks, D. M. D., van Huissteden, J., Dolman, A. J., and van der Molen, M. K.: The full greenhouse gas balance of an abandoned peat meadow, Biogeosciences, 4, 411-424, https://doi.org/10.5194/bg-4-411-2007, 2007.

Hirano, T., Hirata, R., Fujinuma, Y., Saigusa, N., Yamamoto, S., Harazono, Y., Takada, M., Inukai, K., and Inoue, G.: $\mathrm{CO}_{2}$ and water vapor exchange of a larch forest in northern Japan, Tellus B, 55, 244-257, 2003.

Högberg, P., Nordgren, A., Buchmann, N., Taylor, A. F., Ekblad, A., Högberg, M. N., Nyberg, G., Ottosson-Löfvenius, M., and Read, D. J.: Large-scale forest girdling shows that current photosynthesis drives soil respiration, Nature, 411, 789-792, https://doi.org/10.1038/35081058, 2001.

Hollinger, D. Y., Aber, J., Dail, B., Davidson, E. A., Goltz, S. M., Hughes, H., Leclerc, M. Y., Lee, J. T., Richardson, A. D., Rodrigues, C., and Scott, N. A.: Spatial and temporal variability in forest-atmosphere $\mathrm{CO}_{2}$ exchange, Glob. Change Biol., 10, 1689-1706, 2004.

Huybers, P. and Curry, W.: Links between annual, Milankovitch and continuum temperature variability, Nature, 441, 329-332, 2006.

Irvine, J., Law, B. E., and Kurpius, M. R.: Coupling of canopy gas exchange with root and rhizosphere respiration in a semi-arid forest, Biogeochemistry, 73, 271-282, https://doi.org/10.1007/s10533-004-2564-x, 2005.

Irvine, J., Law, B. E., Martin, J. G., and Vickers, D.: Interannual variation in soil $\mathrm{CO}_{2}$ efflux and the response of root respiration to climate and canopy gas exchange in mature ponderosa pine, Glob. Change Biol., 14, 2848-2859, https://doi.org/10.1111/j.1365-2486.2008.01682.x, 2008.

Jarvis, P., Massheder, J., Hale, S., Moncrieff, J., Rayment, M., and Scott, S.: Seasonal variation of carbon dioxide, water vapor, and energy exchanges of a boreal black spruce forest, J. Geophys. Res.-Atmos., 102, 28953-28966, 1997.

Jassal, R. S., Black, T. A., Novak, M. D., Gaumont-Guay, D., and Nesic, Z.: Effect of soil water stress on soil respiration and its temperature sensitivity in an 18-year-old temperate Douglas-fir stand, Glob. Change Biol., 14, 1305-1318, 2008.

Jassal, R. S., Black, T. A., and Nesic, Z.: Biophysical controls of soil $\mathrm{CO}_{2}$ efflux in two coastal Douglas-fir stands at different temporal scales, Agr. Forest Meteorol., 153, 134-143, 2012. 
Jung, M., Reichstein, M., Schwalm, C. R., Huntingford, C., Sitch, S., Ahlström, A., Arneth, A., Camps-Valls, G., Ciais, P., Friedlingstein, P., Gans, F., Ichii, K., Jain, A. K., Kato, E., Papale, D., Poulter, B., Raduly, B., Rödenbeck, C., Tramontana, G., Viovy, N., Wang, Y.-P., Weber, U., Zaehle, S., and Zeng, N.: Compensatory water effects link yearly global land $\mathrm{CO}_{2}$ sink changes to temperature, Nature, 541, 516-520, https://doi.org/10.1038/nature20780, 2017.

Kätterer, T., Reichstein, M., Andrén, O., and Lomander, A.: Temperature dependence of organic matter decomposition: a critical review using literature data analyzed with different models, Biol. Fert. Soils, 27, 258-262, 1998.

Keenan, T., Sabate, S., and Gracia, C.: The importance of mesophyll conductance in regulating forest ecosystem productivity during drought periods, Glob. Change Biol., 16, 1019-1034, https://doi.org/10.1111/j.1365-2486.2009.02017.x, 2010.

Kirschbaum, M. U. F.: The temperature dependence of soil organicmatter decompositopn and the effect of global warming on soil organic C storage, Soil Biol. Biochem., 27, 753-760, https://doi.org/10.1016/0038-0717(94)00242-S, 1995.

Kirschbaum, M. U. F.: The temperature dependence of organic-matter decomposition-still a topic of debate, Soil Biol. Biochem., 38, 2510-2518, https://doi.org/10.1016/j.soilbio.2006.01.030, 2006.

Knohl, A., Schulze, E.-D., Kolle, O., and Buchmann, N.: Large carbon uptake by an unmanaged 250-year-old deciduous forest in Central Germany, Agr. Forest Meteorol., 118, 151-167, 2003.

Kottek, M., Grieser, J., Beck, C., Rudolf, B., and Rubel, F.: World map of the Köppen-Geiger climate classification updated, Meteorol. Z., 15, 259-263, 2006.

Krishnan, P., Black, T. A., Grant, N. J., Barr, A. G., Hogg, E. T. H., Jassal, R. S., and Morgenstern, K.: Impact of changing soil moisture distribution on net ecosystem productivity of a boreal aspen forest during and following drought, Agr. Forest Meteorol., 139, 208-223, 2006.

Kurbatova, J., Li, C., Varlagin, A., Xiao, X., and Vygodskaya, N.: Modeling carbon dynamics in two adjacent spruce forests with different soil conditions in Russia, Biogeosciences, 5, 969-980, 2008.

Lafleur, P. M., Roulet, N. T., Bubier, J. L., Frolking, S., and Moore, T. R.: Interannual variability in the peatland-atmosphere carbon dioxide exchange at an ombrotrophic bog, Global Biogeochem. Cy., 17, 1036, https://doi.org/10.1029/2002GB001983, 2003.

Lagergren, F., Lindroth, A., Dellwik, E., Ibrom, A., Lankreijer, H., Launiainen, S., Mölder, M., Kolari, P., Pilegaard, K., and Vesala, T.: Biophysical controls on $\mathrm{CO}_{2}$ fluxes of three northern forests based on long-term eddy covariance data, Tellus B, 60, 143-152, 2008

Larcher, W.: Physiological plant ecology: ecophysiology and stress physiology of functional groups, Springer Verlag, Berlin, Heidelberg, Germany and New York, NY, USA, 4th Edn., 2003.

Law, B.: Carbon dynamics in response to climate and disturbance: Recent progress from multi-scale measurements and modeling in Ameriflux, in: Plant Responses to Air Pollution and Global Change, edited by: Omasa, K., Nouchi, I., and Kok, L. J. D., 205213, Springer Japan, https://doi.org/10.1007/4-431-31014-2_23, 2005

Law, B., Thornton, P., Irvine, J., Anthoni, P., and Van Tuyl, S.: Carbon storage and fluxes in ponderosa pine forests at dif- ferent developmental stages, Glob. Change Biol., 7, 755-777, https://doi.org/10.1046/j.1354-1013.2001.00439.x, 2001.

Law, B. E.: Regional analysis of drought and heat impacts on forests: current and future science directions, Glob. Change Biol., 20, 3595-3599, https://doi.org/10.1111/gcb.12651, 2014.

Law, B. E., Ryan, M. G., and Anthoni, P. M.: Seasonal and annual respiration of a ponderosa pine ecosystem, Glob. Change Biol., 5, 169-182, https://doi.org/10.1046/j.1365-2486.1999.00214.x, 1999.

Leonard, M., Westra, S., Phatak, A., Lambert, M., van den Hurk, B., McInnes, K., Risbey, J., Schuster, S., Jakob, D., and StaffordSmith, M.: A compound event framework for understanding extreme impacts, Wiley Interdisciplinary Reviews: Climate Change, 5, 113-128, 2014.

Leuning, R.: Modelling stomatal behaviour and photosynthesis of Eucalyptus grandis, Funct. Plant Biol., 17, 159-175, 1990.

Lipson, D. A., Wilson, R. F., and Oechel, W. C.: Effects of elevated atmospheric $\mathrm{CO}_{2}$ on soil microbial biomass, activity, and diversity in a chaparral ecosystem, Appl. Environ. Microbiol., 71, 8573-8580, 2005.

Liu, W., Zhang, Z., and Wan, S.: Predominant role of water in regulating soil and microbial respiration and their responses to climate change in a semiarid grassland, Glob. Change Biol., 15, 184-195, https://doi.org/10.1111/j.1365-2486.2008.01728.x, 2009.

Lloyd, J. and Taylor, J. A.: On the temperature dependence of soil respiration, Funct. Ecol., 8, 315-323, https://doi.org/10.2307/2389824, 1994.

Ma, S., Baldocchi, D. D., Xu, L., and Hehn, T.: Inter-annual variability in carbon dioxide exchange of an oak/grass savanna and open grassland in California, Agr. Forest Meteorol., 147, 157$171,2007$.

Mahecha, M. D., Reichstein, M., Carvalhais, N., Lasslop, G., Lange, H., Seneviratne, S. I., Vargas, R., Ammann, C., Arain, M. A., Cescatti, A., Janssens, I. A., Migliavacca, M., Montagnani, L., and Richardson, A. D.: Global convergence in the temperature sensitivity of respiration at ecosystem level, Science, 329, 838-840, https://doi.org/10.1126/science.1189587, 2010.

Mahecha, M. D., Gans, F., Sippel, S., Donges, J. F., Kaminski, T., Metzger, S., Migliavacca, M., Papale, D., Rammig, A., and Zscheischler, J.: Detecting impacts of extreme events with ecological in situ monitoring networks, Biogeosciences, 14, 42554277, https://doi.org/10.5194/bg-14-4255-2017, 2017.

Marcolla, B. and Cescatti, A.: Experimental analysis of flux footprint for varying stability conditions in an alpine meadow, Agr. Forest Meteorol., 135, 291-301, 2005.

Marek, M. V., Janouš, D., Taufarová, K., Havránková, K., Pavelka, M., Kaplan, V., and Marková, I.: Carbon exchange between ecosystems and atmosphere in the Czech Republic is affected by climate factors, Environ. Pollut., 159, 1035-1039, 2011.

Maselli, F., Barbati, A., Chiesi, M., Chirici, G., and Corona, P.: Use of remotely sensed and ancillary data for estimating forest gross primary productivity in Italy, Remote Sens. Environ., 100, 563575, 2006.

Medlyn, B. E., Dreyer, E., Ellsworth, D., Forstreuter, M., Harley, P. C., Kirschbaum, M. U. F., Le Roux, X., Montpied, P., Strassemeyer, J., Walcroft, A., Wang, K., and Loustau, D.: Temperature response of parameters of a biochemically based model of photo- 
synthesis. II. A review of experimental data, Plant Cell Environ., 25, 1167-1179, 2002.

Meir, P., Metcalfe, D., Costa, A., and Fisher, R.: The fate of assimilated carbon during drought: Impacts on respiration in Amazon rainforests, Philos. T. Roy. Soc. B, 363, 1849-1855, https://doi.org/10.1098/rstb.2007.0021, 2008.

Meyers, T. P. and Hollinger, S. E.: An assessment of storage terms in the surface energy balance of maize and soybean, Agr. Forest Meteorol., 125, 105-115, 2004.

Michelot, A., Eglin, T., Dufrene, E., Lelarge-Trouverie, C., and Damesin, C.: Comparison of seasonal variations in water-use efficiency calculated from the carbon isotope composition of tree rings and flux data in a temperate forest, Plant Cell Environ., 34, 230-244, 2011.

Migliavacca, M., Reichstein, M., Richardson, A. D., Colombo, R., Sutton, M. A., Lasslop, G., Tomerelli, E., Wohlfahrt, G., Carvalais, N., Cescatti, A., Mahecha, M. D., Montagnani, L., Papale, D., Zaehle, S., Arain, A., Arneth, A., Black, T. A., Carrara, A., Dore, S., Gianelle, D., Helfter, C., Hollinger, D., Kutsch, W. L., Lafleur, P. M., Nouvellon, Y., Rebmann, C., Da Rocha, H. R., Rodeghiero, M., Roupsard, O., Sebastian, M.-T., Seuffert, G., Soussana, J.-F., and Van Der Molen, M. K.: Semiempirical modeling of abiotic and biotic factors controlling ecosystem respiration across Eddy Covariance sites, Glob. Change Biol., 17, 390409, https://doi.org/10.1111/j.1365-2486.2010.02243.x, 2010.

Moncrieff, J. B., Massheder, J. M., deBruin, H., Elbers, J., Friborg, T., Heusinkveld, B., Kabat, P., Scott, S., Soegaard, H., and Verhoef, A.: A system to measure surface fluxes of momentum, sensible heat, water vapour and carbon dioxide, J. Hydrol., 189, 589-611, 1997.

Monson, R., Turnipseed, A., Sparks, J., Harley, P., Scott-Denton, L., Sparks, K., and Huxman, T.: Carbon sequestration in a highelevation, subalpine forest, Glob. Change Biol., 8, 459-478, 2002.

Morgenstern, K., Black, T. A., Humphreys, E. R., Griffis, T. J., Drewitt, G. B., Cai, T., Nesic, Z., Spittlehouse, D. L., and Livingston, N. J.: Sensitivity and uncertainty of the carbon balance of a Pacific Northwest Douglas-fir forest during an El Niño/La Niña cycle, Agr. Forest Meteorol., 123, 201-219, 2004.

Moureaux, C., Debacq, A., Bodson, B., Heinesch, B., and Aubinet, M.: Annual net ecosystem carbon exchange by a sugar beet crop, Agr. Forest Meteorol., 139, 25-39, 2006.

Muhr, J., Franke, J., and Borken, W.: Drying-rewetting events reduce $\mathrm{C}$ and $\mathrm{N}$ losses from a Norway spruce forest floor, Soil Biol. Biochem., 42, 1303-1312, 2010.

Murray-Tortarolo, G., Friedlingstein, P., Sitch, S., Seneviratne, S. I., Fletcher, I., Mueller, B., Greve, P., Anav, A., Liu, Y., Ahlström, A., and Huntingford, C.: The dry season intensity as a key driver of NPP trends, Geophys. Res. Lett., 43, 2632-2639, 2016.

Nagy, Z., Pintér, K., Czóbel, S., Balogh, J., Horváth, L., Fóti, S., Barcza, Z., Weidinger, T., Csintalan, Z., Dinh, N. Q., Grosz, B., and Tuba, Z.: The carbon budget of semi-arid grassland in a wet and a dry year in Hungary, Agr. Ecosyst. Environ., 121, 21-29, https://doi.org/10.1016/j.agee.2006.12.003, 2007.

Nardino, M., Georgiadis, T., Rossi, F., Ponti, F., Miglietta, F., and Magliulo, V.: Primary productivity and evapotranspiration of a mixed forest, in: Congress CNR-ISA Fo., Istituto per i Sistemi Agricoli e Forestali del Mediterraneo, Portici, 24-25, 2002.
Nemani, R. R., Keeling, C. D., Hashimoto, H., Jolly, W. M., Piper, S. C., Tucker, C. J., Myneni, R. B., and Running, S. W.: Climatedriven increases in global terrestrial net primary production from 1982 to 1999, Science, 300, 1560-1563, 2003.

Orchard, V. and Cook, F.: Relationship between soil respiration and soil-moisture, Soil Biol. Biochem., 15, 447-453, https://doi.org/10.1016/0038-0717(83)90010-X, 1983.

Pataki, D. E. and Oren, R.: Species differences in stomatal control of water loss at the canopy scale in a mature bottomland deciduous forest, Adv. Water Resour., 26, 1267-1278, 2003.

Peichl, M., Leahy, P., and Kiely, G.: Six-year stable annual uptake of carbon dioxide in intensively managed humid temperate grassland, Ecosystems, 14, 112-126, 2011.

Peichl, M., Sonnentag, O., Wohlfahrt, G., Flanagan, L. B., Baldocchi, D. D., Kiely, G., Galvagno, M., Gianelle, D., Marcolla, B., Pio, C., Migliavacca, M., Jones, M. B., and Saunders, M.: Convergence of potential net ecosystem production among contrasting C3 grasslands, Ecol. Lett., 16, 502-512, https://doi.org/10.1111/ele.12075, 2013.

Pereira, J. S., Mateus, J. A., Aires, L. M., Pita, G., Pio, C., David, J. S., Andrade, V., Banza, J., David, T. S., Paço, T. A., and Rodrigues, A.: Net ecosystem carbon exchange in three contrasting Mediterranean ecosystems - the effect of drought, Biogeosciences, 4, 791-802, https://doi.org/10.5194/bg-4-7912007, 2007.

Perez-Priego, O., El-Madany, T. S., Migliavacca, M., Kowalski, A. S., Jung, M., Carrara, A., Kolle, O., Martín, M. P., Pacheco-Labrador, J., Moreno, G., and Reichstein, M.: Evaluation of eddy covariance latent heat fluxes with independent lysimeter and sapflow estimates in a Mediterranean savannah ecosystem, Agr. Forest Meteorol., 236, 87-99, https://doi.org/10.1016/j.agrformet.2017.01.009, 2017.

Pilegaard, K., Hummelshøj, P., Jensen, N., and Chen, Z.: Two years of continuous $\mathrm{CO}_{2}$ eddy-flux measurements over a Danish beech forest, Agr. Forest Meteorol., 107, 29-41, 2001.

Powell, T. L., Bracho, R., Li, J., Dore, S., Hinkle, C. R., and Drake, B. G.: Environmental controls over net ecosystem carbon exchange of scrub oak in central Florida, Agr. Forest Meteorol., 141, 19-34, 2006.

Priestley, C. and Taylor, R.: On the assessment of surface heat flux and evaporation using large-scale parameters, Mon. Weather Rev., 100, 81-92, 1972.

Rambal, S., Joffre, R., Ourcival, J., Cavender-Bares, J., and Rocheteau, A.: The growth respiration component in eddy $\mathrm{CO}_{2}$ flux from a Quercus ilex mediterranean forest, Glob. Change Biol., 10, 1460-1469, 2004.

Rambal, S., Lempereur, M., Limousin, J. M., Martin-StPaul, N. K., Ourcival, J. M., and Rodríguez-Calcerrada, J.: How drought severity constrains gross primary production (GPP) and its partitioning among carbon pools in a Quercus ilex coppice?, Biogeosciences, 11, 6855-6869, https://doi.org/10.5194/bg-11-68552014, 2014.

Reichstein, M. and Beer, C.: Soil respiration across scales: The importance of a model-data integration framework for data interpretation, J. Plant Nutr. Soil Sc., 171, 344-354, 2008.

Reichstein, M., Tenhunen, J. D., Roupsard, O., Ourcival, J.-M., Rambal, S., Miglietta, F., Peressotti, A., Pecchiari, M., Tirone, G., and Valentini, R.: Severe drought effects on ecosystem $\mathrm{CO}_{2}$ and $\mathrm{H}_{2} \mathrm{O}$ fluxes at three Mediterranean evergreen sites: revi- 
sion of current hypotheses?, Glob. Change Biol., 8, 999-1017, https://doi.org/10.1046/j.1365-2486.2002.00530.x, 2002.

Reichstein, M., Falge, E., Baldocchi, D., Papale, D., Aubinet, M., Berbigier, P., Bernhofer, C., Buchmann, N., Gilmanov, T., Granier, A., Grunwald, T., Havrankova, K., Ilvesniemi, H., Janous, D., Knohl, A., Laurila, T., Lohila, A., Loustau, D., Matteucci, G., Meyers, T., Miglietta, F., Ourcival, J. M., Pumpanen, J., Rambal, S., Rotenberg, E., Sanz, M., Tenhunen, J., Seufert, G., Vaccari, F., Vesala, T., Yakir, D., and Valentini, R.: On the separation of net ecosystem exchange into assimilation and ecosystem respiration: review and improved algorithm, Glob. Change Biol., 11, 1424-1439, 2005.

Reichstein, M., Ciais, P., Papale, D., Valentini, R., Running, S., Viovy, N., Cramer, W., Granier, A., Ogée, J., Allard, V., Aubinet, M., Bernhofer, C., Buchmann, N., Carrara, A., Grünwald, T., Heimann, M., Heinesch, B., Knohl, A., Kutsch, W., Loustau, D., Manca, G., Matteucci, G., Miglietta, F., Ourcival, J., Pilegaard, K., Pumpanen, J., Rambal, S., Schaphoff, S., Seufert, G., Soussana, J.-F., Sanz, M.-J., Vesala, T., and Zhao, M.: Reduction of ecosystem productivity and respiration during the European summer 2003 climate anomaly: a joint flux tower, remote sensing and modelling analysis, Glob. Change Biol., 13, 634-651, https://doi.org/10.1111/j.1365-2486.2006.01224.x, 2007.

Reichstein, M., Bahn, M., Ciais, P., Frank, D., Mahecha, M. D., Seneviratne, S. I., Zscheischler, J., Beer, C., Buchmann, N., Frank, D. C., Papale, D., Rammig, A., Smith, P., Thonicke, K., van der Velde, M., Vicca, S., Walz, A., and Wattenbach, M.: Climate extremes and the carbon cycle, Nature, 500, 287-295, https://doi.org/10.1038/nature12350, 2013.

Rodrigues, A., Pita, G., Mateus, J. a., Kurz-Besson, C., Casquilho, M., Cerasoli, S., Gomes, A., and Pereira, J. A.: Eight years of continuous carbon fluxes measurements in a Portuguese eucalypt stand under two main events: Drought and felling, Agr. Forest Meteorol., 151, 493-507, 2011.

Roman, D., Novick, K., Brzostek, E., Dragoni, D., Rahman, F., and Phillips, R.: The role of isohydric and anisohydric species in determining ecosystem-scale response to severe drought, Oecologia, 179, 641-654, 2015.

Ruehr, N. K., Martin, J. G., and Law, B. E.: Effects of water availability on carbon and water exchange in a young ponderosa pine forest: Above-and belowground responses, Agr. Forest Meteorol., 164, 136-148, 2012.

Rustad, L., Campbell, J., Marion, G., Norby, R., Mitchell, M., Hartley, A., Cornelissen, J., and Gurevitch, J.: A meta-analysis of the response of soil respiration, net nitrogen mineralization, and aboveground plant growth to experimental ecosystem warming, Oecologia, 126, 543-562, 2001.

Ryan, M. G. and Law, B. E.: Interpreting, measuring, and modeling soil respiration, Biogeochemistry, 73, 3-27, https://doi.org/10.1007/s10533-004-5167-7, 2005.

Sage, R. F. and Kubien, D. S.: The temperature response of $\mathrm{C}_{3}$ and $\mathrm{C}_{4}$ photosynthesis, Plant Cell Environ., 30, 1086-1106, https://doi.org/10.1111/j.1365-3040.2007.01682.x, 2007.

Sagerfors, J., Lindroth, A., Grelle, A., Klemedtsson, L., Weslien, P., and Nilsson, M.: Annual $\mathrm{CO}_{2}$ exchange between a nutrient-poor, minerotrophic, boreal mire and the atmosphere, J. Geophys. Res.-Biogeo., 113, G01001, https://doi.org/10.1029/2006JG000306, 2008.
Salvucci, M. E. and Crafts-Brandner, S. J.: Inhibition of photosynthesis by heat stress: the activation state of Rubisco as a limiting factor in photosynthesis, Physiol. Plantarum, 120, 179-186, https://doi.org/10.1111/j.0031-9317.2004.0173.x, 2004.

Schulze, E. D.: Carbon-dioxide and water-vapor exchange in response to drought in the atmosphere and in the soil, Annu. Rev. Plant Phys., 37, 247-274, 1986.

Schwalm, C. R., Williams, C. A., Schaefer, K., Arneth, A., Bonal, D., Buchmann, N., Chen, J., Law, B. E., Lindroth, A., Luyssaert, S., Reichstein, M., and Richardson, A. D.: Assimilation exceeds respiration sensitivity to drought: A FLUXNET synthesis, Glob. Change Biol., 16, 657-670, https://doi.org/10.1111/j.13652486.2009.01991.x, 2010.

Schwalm, C. R., Williams, C. A., Schaefer, K., Baldocchi, D., Black, T. A., Goldstein, A. H., Law, B. E., Oechel, W. C., and Scott, R. L.: Reduction in carbon uptake during turn of the century drought in western North America, Nat. Geosci., 5, 551556, 2012.

Scott, R. L., Jenerette, G. D., Potts, D. L., and Huxman, T. E.: Effects of seasonal drought on net carbon dioxide exchange from a woody-plant-encroached semiarid grassland, J. Geophys. Res.Biogeo., 114, G04004, https://doi.org/10.1029/2008JG000900, 2009.

Seneviratne, S. I., Corti, T., Davin, E. L., Hirschi, M., Jaeger, E. B., Lehner, I., Orlowsky, B., and Teuling, A. J.: Investigating soil moisture-climate interactions in a changing climate: A review, Earth-Sci. Rev., 99, 125-161, 2010.

Seneviratne, S. I., Nicholls, N., Easterling, D., Goodess, C. M., Kanae, S., Kossin, J., Luo, Y., Marengo, J., McInnes, K., Rahimi, M., Reichstein, M., Sorteberg, A., Vera, C., and Zhang, X.: Changes in climate extremes and their impacts on the natural physical environment, in: Managing the Risks of Extreme Events and Disasters to Advance Climate Change Adaptation, edited by: Field, C. B., Barros, V., Stocker, T. F., Qin, D., Dokken, D. J., Ebi, K. L., Mastrandrea, M. D., Mach, K. J., Plattner, G.-K., Allen, S. K., Tignor, M., and Midgley, P. M., A Special Report of Working Groups I and II of the Intergovernmental Panel on Climate Change (IPCC), Cambridge University Press, Cambridge, UK, and New York, NY, USA, 109-230, 2012.

Sheik, C. S., Beasley, W. H., Elshahed, M. S., Zhou, X., Luo, Y., and Krumholz, L. R.: Effect of warming and drought on grassland microbial communities, ISME J., 5, 1692-1700, 2011.

Sillmann, J., Kharin, V. V., Zhang, X., Zwiers, F. W., and Bronaugh, D.: Climate extremes indices in the CMIP5 multimodel ensemble: Part 1. Model evaluation in the present climate, J. Geophys. Res.-Atmos., 118, 1716-1733, 2013 a.

Sillmann, J., Kharin, V. V., Zwiers, F. W., Zhang, X., and Bronaugh, D.: Climate extremes indices in the CMIP5 multimodel ensemble: Part 2. Future climate projections, J. Geophys. Res.-Atmos., 118, 2473-2493, 2013b.

Smith, M. D.: An ecological perspective on extreme climatic events: a synthetic definition and framework to guide future research, J. Ecology, 99, 656-663, https://doi.org/10.1111/j.13652745.2011.01798.x, 2011.

Teuling, A. J. and Seneviratne, S. I.: The contrasting role of forests and grasslands on land-climate interaction during recent European heat waves, in: Earth Observation for Land-Atmosphere Interaction Science, Vol. 688, p. 23, 2011. 
Teuling, A. J., Hirschi, M., Ohmura, A., Wild, M., Reichstein, M., Ciais, P., Buchmann, N., Ammann, C., Montagnani, L., Richardson, A. D., Wohlfahrt, G., and Seneviratne, S. I.: A regional perspective on trends in continental evaporation, Geophys. Res. Lett., 36, L02404, https://doi.org/10.1029/2008GL036584, 2009.

Teuling, A. J., Seneviratne, S. I., Stöckli, R., Reichstein, M., Moors, E., Ciais, P., Luyssaert, S., van den Hurk, B., Ammann, C., Bernhofer, C., Dellwik, E., Gianelle, D., Gielen, B., Grünwald, T., Klumpp, K., Montagnani, L., Moureaux, C., Sottocornola, M., and Wohlfahrt, G.: Contrasting response of European forest and grassland energy exchange to heatwaves, Nat. Geosci., 3, 722727, https://doi.org/10.1038/ngeo950, 2010.

Thomas, C. K., Law, B. E., Irvine, J., Martin, J. G., Pettijohn, J. C., and Davis, K. J.: Seasonal hydrology explains interannual and seasonal variation in carbon and water exchange in a semiarid mature ponderosa pine forest in central Oregon, J. Geophys. Res., 114, G04006, https://doi.org/10.1029/2009JG001010, 2009.

Thum, T., Aalto, T., Laurila, T., Aurela, M., Kolari, P., and Hari, P.: Parametrization of two photosynthesis models at the canopy scale in a northern boreal Scots pine forest, Tellus B, 59, 874890, 2007.

Tirone, G., Dore, S., Matteucci, G., Greco, S., and Valentini, R.: Evergreen Mediterranean forests. carbon and water fluxes, balances, ecological and ecophysiological determinants, in: Fluxes of Carbon, Water and Energy of European Forests, 125-149, Springer, 2003.

Tramontana, G., Jung, M., Schwalm, C. R., Ichii, K., Camps-Valls, G., Ráduly, B., Reichstein, M., Arain, M. A., Cescatti, A., Kiely, G., Merbold, L., Serrano-Ortiz, P., Sickert, S., Wolf, S., and Papale, D.: Predicting carbon dioxide and energy fluxes across global FLUXNET sites with regression algorithms, Biogeosciences, 13, 4291-4313, https://doi.org/10.5194/bg-13-42912016, 2016.

Vaccari, F. P., Lugato, E., Gioli, B., D’Acqui, L., Genesio, L., Toscano, P., Matese, A., and Miglietta, F.: Land use change and soil organic carbon dynamics in Mediterranean agro-ecosystems: The case study of Pianosa Island, Geoderma, 175, 29-36, https://doi.org/10.1016/j.geoderma.2012.01.021, 2012.

Valentini, R., Matteucci, G., Dolman, A. J., Schulze, E. D., Rebmann, C. J. M. E. A. G., Moors, E. J., Granier, A., Gross, P., Jensen, N. O., Pilegaard, K., and Lindroth, A.: Respiration as the main determinant of carbon balance in European forests, Nature, 404, 861-865, 2000.

van der Molen, M. K., Dolman, A. J., Ciais, P., Eglin, T., Gobron, N., Law, B. E., Meir, P., Peters, W., Phillips, O. L., Reichstein, M., and Chen, T.: Drought and ecosystem carbon cycling, Agricultural and Forest Meteorology, 151, 765-773, 2011.

van Gorsel, E., Wolf, S., Cleverly, J., Isaac, P., Haverd, V., Ewenz, C., Arndt, S., Beringer, J., Resco de Dios, V., Evans, B. J., Griebel, A., Hutley, L. B., Keenan, T., Kljun, N., Macfarlane, C., Meyer, W. S., McHugh, I., Pendall, E., Prober, S. M., and Silberstein, R.: Carbon uptake and water use in woodlands and forests in southern Australia during an extreme heat wave event in the “Angry Summer" of 2012/2013, Biogeosciences, 13, 5947-5964, https://doi.org/10.5194/bg-13-5947-2016, 2016.

van't Hoff, J. H.: Lectures on theoretical and physical chemistry, E. Arnold, London, 1898.
Vetter, M., Churkina, G., Jung, M., Reichstein, M., Zaehle, S., Bondeau, A., Chen, Y., Ciais, P., Feser, F., Freibauer, A., Geyer, R., Jones, C., Papale, D., Tenhunen, J., Tomelleri, E., Trusilova, K., Viovy, N., and Heimann, M.: Analyzing the causes and spatial pattern of the European 2003 carbon flux anomaly using seven models, Biogeosciences, 5, 561-583, https://doi.org/10.5194/bg5-561-2008, 2008.

Williams, M., Richardson, A. D., Reichstein, M., Stoy, P. C., Peylin, P., Verbeeck, H., Carvalhais, N., Jung, M., Hollinger, D. Y., Kattge, J., Leuning, R., Luo, Y., Tomelleri, E., Trudinger, C. M., and Wang, Y.-P.: Improving land surface models with FLUXNET data, Biogeosciences, 6, 1341-1359, https://doi.org/10.5194/bg6-1341-2009, 2009.

Wohlfahrt, G. and Gu, L.: The many meanings of gross photosynthesis and their implication for photosynthesis research from leaf to globe, Plant Cell Environ., 38, 2500-2507, 2015.

Wohlfahrt, G., Anderson-Dunn, M., Bahn, M., Balzarolo, M., Berninger, F., Campbell, C., Carrara, A., Cescatti, A., Christensen, T., Dore, S., Eugster, W., Friborg, T., Furger, M., Gianelle, D., Gimeno, C., Hargreaves, K., Hari, P., Haslwanter, A., Johansson, T., Marcolla, B., Milford, C., Nagy, Z., Nemitz, E., Rogiers, N., Sanz, M. J., Siegwolf, R. T., Susiluoto, S., Sutton, M., Tuba, Z., Ugolini, F., Valentini, R., Zorer, R., and Cernusca, A.: Biotic, abiotic, and management controls on the net ecosystem $\mathrm{CO}_{2}$ exchange of European mountain grassland ecosystems, Ecosystems, 11, 1338-1351, https://doi.org/10.1007/s10021008-9196-2, 2008.

Wolf, S., Eugster, W., Ammann, C., Häni, M., Zielis, S., Hiller, R., Stieger, J., Imer, D., Merbold, L., and Buchmann, N.: Contrasting response of grassland versus forest carbon and water fluxes to spring drought in Switzerland, Environ. Res. Lett., 8, 035007, https://doi.org/10.1088/1748-9326/8/3/035007, 2013.

Wolf, S., Keenan, T. F., Fisher, J. B., Baldocchi, D. D., Desai, A. R., Richardson, A. D., Scott, R. L., Law, B. E., Litvak, M. E., Brunsell, N. A., and Peters, W.: Warm spring reduced carbon cycle impact of the 2012 US summer drought, P. Natl. Acad. Sci. USA, 113, 5880-5885, 2016.

Wu, S. H., Jansson, P.-E., and Kolari, P.: Modeling seasonal course of carbon fluxes and evapotranspiration in response to low temperature and moisture in a boreal Scots pine ecosystem, Ecol. Model., 222, 3103-3119, 2011.

$\mathrm{Xu}, \mathrm{L}$. and Baldocchi, D. D.: Seasonal variation in carbon dioxide exchange over a Mediterranean annual grassland in California, Agr. Forest Meteorol., 123, 79-96, 2004.

Yamamoto, S., Murayama, S., Saigusa, N., and Kondo, H.: Seasonal and inter-annual variation of $\mathrm{CO}_{2}$ flux between a temperate forest and the atmosphere in Japan, Tellus B, 51, 402-413, 1999.

Zhao, M. and Running, S. W.: Drought-induced reduction in global terrestrial net primary production from 2000 through 2009, Science, 329, 940-943, 2010.

Zscheischler, J. and Seneviratne, S. I.: Dependence of drivers affects risks associated with compound events, Science Advances, 3, e1700263, https://doi.org/10.1126/sciadv.1700263, 2017.

Zscheischler, J., Mahecha, M. D., Buttlar, J. v., Harmeling, S., Jung, M., Rammig, A., Randerson, J. T., Schólkopf, B., Seneviratne, S. I., Tomelleri, E., Zaehle, S., and Reichstein, M.: A few extreme events dominate global interannual variability in gross primary production, Environ. Res. Lett., 9, 035001, https://doi.org/10.1088/1748-9326/9/3/035001, 2014a. 
Zscheischler, J., Michalak, A. M., Schwalm, C., Mahecha, M. D., Huntzinger, D. N., Reichstein, M., Berthier, G., Ciais, P., Cook, R. B., El-Masri, B., Huang, M., Ito, A., Jain, A., King, A., Lei, H., Lu, C., Mao, J., Peng, S., Poulter, B., Ricciuto, D., Shi, X., Tao, B., Tian, H., Viovy, N., Wang, W., Wei, Y., Yang, J., and Zeng, N.: Impact of large-scale climate extremes on biospheric carbon fluxes: An intercomparison based on MsTMIP data, Global Biogeochem. Cy., 28, 585-600, https://doi.org/10.1002/2014GB004826, 2014b.
Zscheischler, J., Reichstein, M., Harmeling, S., Rammig, A., Tomelleri, E., and Mahecha, M. D.: Extreme events in gross primary production: a characterization across continents, Biogeosciences, 11, 2909-2924, https://doi.org/10.5194/bg-11-29092014, 2014c.

Zscheischler, J., Reichstein, M., von Buttlar, J., Mu, M., Randerson, J. T., and Mahecha, M. D.: Carbon cycle extremes during the 21st century in CMIP5 models: Future evolution and attribution to climatic drivers, Geophys. Res. Lett., 41, 8853-8861, 2014 d. 